\title{
Diversity of tree-infecting Botryosphaeriales on native and non-native trees in South Africa and Namibia
}

Fahimeh Jami ${ }^{1, *}$, Michael J. Wingfield ${ }^{1}$, Marieka Gryzenhout ${ }^{2}$ and Bernard Slippers ${ }^{3}$

\footnotetext{
${ }^{1}$ Department of Microbiology and Plant Pathology, Forestry \& Agricultural Biotechnology Institute (FABI), University of Pretoria, Pretoria, South Africa

${ }^{2}$ Department of Genetics, University of the Free State, Bloemfontein, South Africa

${ }^{3}$ Department of Genetics, Forestry \& Agricultural Biotechnology Institute (FABI), University of Pretoria, Pretoria, South Africa
}

*Correspondence to: Fahimeh Jami

Fahimeh.jami@fabi.up.ac.za

\begin{abstract}
The Botryosphaeriales includes serious plant pathogens with a broad host and geographic distribution globally. In South Africa and Namibia, these fungi include important pathogens of native and non-native woody plants, and have consequently been studied extensively. Here we synthesize the information from the previous studies, particularly in the last decade, that report 62 species in the Botryosphaeriales from 66 hosts across South Africa and Namibia. Of these, 52 species have been reported from native hosts, 17 are from nonnative hosts and twelve of these species occur on both native and non-native trees in the region. Much of the diversity of the Botryosphaeriales can be ascribed to native species that have fairly limited host and geographic ranges. Neofusicoccum parvum is amongst the most common species on both native and non-native hosts and it is thought to be native to the region. In contrast, Botryosphaeria dothidea, which is certainly an introduced species, is also widespread, and is very common on both native and non-native plants. Overall this synthesis underscores the growing understanding of the diversity of an important group of tree pathogens, their apparently common global spread as latent agents of disease, as well as their apparently common movement between commercial and native ecosystems.
\end{abstract}

\section{Keywords}

Aplosporellaceae; Botryosphaeriales; Pseudofusicoccumaceae; Saccharataceae; Host association; Fungal biogeography

\section{Introduction}

Woody plants are often colonized by Botryosphaeriales as endophytes, irrespective of whether they are agricultural crops, ornamental plants, plantation forestry species or plants in natural woody vegetation (Slippers and Wingfield 2007; Slippers et al. 2017). Species of 
the Botryosphaeriales include important and common pathogens of native and non-native woody plants worldwide. Consequently, these fungi have been relatively well studied. While they are equally common in native ecosystems, the majority of studies on the Botryosphaeriales have been on agricultural or forestry crops. The overlap between Botryosphaeriales occurring on native and non-native trees is an important feature of these fungi that has only recently been appreciated (Slippers et al. 2009; Sakalidis et al. 2013; Pillay et al. 2013; Marsberg et al. 2017; Slippers et al. 2017; Mehl et al. 2017a).

Advances in DNA based phylogenetic inference and its impact on the taxonomy of fungi during the past two decades has led to the description of many new species, recognition of species complexes and ongoing revisions of older taxa in the Botryosphaeriales. There is consequently great uncertainty regarding identifications of species in this group and particularly those for which no culture and DNA sequence data are available (Crous et al. 2016). Similar problems abound regarding the interpretations of species distributions, host associations, links of species to diseases etc. For example, up until the 1990's, Botryosphaeria dothidea became a repository for many species with 'Fusicoccum-like' asexual states. However, collections typically identified as this species have subsequently been described as various species and genera (Slippers et al. 2013; Phillips et al. 2013; Slippers et al. 2017). Botryosphaeria dothidea has also been reported from South Africa, but recent studies have shown that it is not the most common species in many areas (Jami et al. 2015; Pavlic et al. 2007). It is consequently clear that numerous previous reports recording this pathogen referred not to this species but others in Botryosphaeria or Neofusicoccum.

During the course of the past two decades, a relatively large number of studies have been conducted on the Botryosphaeriales on various plants in South Africa, and to a lesser extent in neighbouring, Namibia. Interestingly, this region has been one of the most intensively studied for this group of fungi anywhere in the world. But commonly, these studies have been focused on a specific disease problem or host, and the broader ecological patterns remain underexplored. In this review we synthesize the information from all reports of Botryosphaeriales from South Africa and Namibia with the overall aim of illustrating patterns of distribution and host association. For accuracy, we base the review only on reports for which identifications and descriptions are linked to DNA-based comparisons.

\section{Botryosphaeriales on native and non-native hosts in South Africa and Namibia}

Sixty-two species of Botryosphaeriales have been identified in studies undertaken in different parts of South Africa and Namibia. These studies have recorded species on 66 native and non-native hosts (Table 1, Figs. 1 and 2). The isolated species included those causing disease symptoms (Fig. 3) and others isolated from asymptomatic tissues.

Neofusicoccum was the most diverse genus identified in these studies, with 16 species described from the region. Neofusicoccum parvum has been found to infect the greatest number of host species (Fig. 4) but $B$. dothidea was the most common species in the sampled sites throughout South Africa. In the following sections, we analyse these patterns of host association and distribution of Botryosphaeriales on native and non-native woody plants in South Africa in greater detail. Other than better understanding the patterns of 
Table 1 Botryosphaeriales associated with southern African native and non-native trees

\begin{tabular}{|c|c|c|c|c|}
\hline Fungus & Host & Symptoms/Plant tissue & Sampled area & Reference \\
\hline Aplosporella africana & Senegalia mellifera & Healthy branches & Dordabis, Namibia & Slippers et al. 2013 \\
\hline A. javeedii & Celtis africana & “ & Gauteng, SA & Jami et al. 2014 Jami \\
\hline A. javeedii & Searsia lancea & “ & “ & et al. 2014 Slippers et \\
\hline A. papillata & Vachellia tortilis & Not available & Northern Cape, SA & al. 2013 Damm et al. \\
\hline A. prunicola & Prunnus persica & “ & Limpopo, SA & 2007 Slippers et al. \\
\hline A. papillata & Vachellia erioloba & “ & Northern Cape, SA & 2013 Mehl et al. 2011 \\
\hline Botryosphaeria atrovirens & Pterocarpus angolensis & Symptomless & Mpumalanga, SA & Slippers et al. 2013 \\
\hline B. avasmontanum & Senegalia mellifera & Not available & Windhoek, Namibia & Mehl et al. 2017b \\
\hline B. fabiceriana & Sclerocarya birrea & & Limpopo, SA & Mehl et al. $2017 b$ \\
\hline B. fabiceriana & Mangifera indica & & Limpopo, SA & Jami et al. 2015 \\
\hline B. dothidea & Vachellia karroo & Healthy branches \& leaves & Gauteng, SA & Slippers et al. 2013 \\
\hline B. dothidea & Vachellia karroo & Not available & Windhoek, Namibia & Roux and Wingfield \\
\hline B. dothidea & Acacia mearnsii & Canker & KwaZulu-Natal, SA & 1997 \\
\hline B. dothidea & Senegalia mellifera & Not available & Dordabis, Namibia & Slippers et al. 2013 \\
\hline B. dothidea & Eucalyptus citriodora & Symptomless & Gauteng, SA & Maleme 2009 \\
\hline B. dothidea & Eucalyptus dorrigoensis & “" & “ & Maleme 2009 \\
\hline B. dothidea & Eucalyptus microcorvs & “ & “ & Maleme 2009 \\
\hline B. dothidea & Eucalyptus spp. & “ & “ & Maleme 2009 \\
\hline B. dothidea & Podocarpuse longatus & Die-back & “ & Ndove 2015 \\
\hline B. dothidea & Podocarpus henkelii & “ & “ & Ndove 2015 \\
\hline B. dothidea & Syzygium cordatum & Canker\& die-back & Eastern Cape, KwaZulu-Natal, SA & Pavlic et al. 2004, 2007 \\
\hline Diplodia africana & Prunnus persica & Canker \& die-back & Western Cape, SA & Damm et al. 2007 \\
\hline D. allocellula & Vachellia karroo & Healthy branches & Gauteng, SA & Jami et al. 2012 \\
\hline D. estuarina & Avicennia marina & " & KwaZulu-Natal, SA & Osorio et al. 2017 \\
\hline D. estuarina & Rhizophora mucronata & “ & $\begin{array}{l}\text { KwaZulu-Natal, Eastern } \\
\text { Cape, SA }\end{array}$ & Osorio et al. 2017 \\
\hline D. mutila & Prunus salicina & Canker\& die-back & Western Cape, SA & Damm et al. 2007 \\
\hline D. mutila & Podocarpus henkelii & Symptomless & “ & Ndove 2015 \\
\hline D. pseudoseriata & Vachellia karroo & Healthy leaves & Gauteng, SA & Jami et al. 2015 \\
\hline D. pseudoseriata & Pterocarpus angolensis & Healthy/ Diseased tissues & Mpumalanga, SA & Mehl et al. 2011 \\
\hline D. sapinea & Cupressus lusitanica & Canker & Mpumalanga, SA & Linde et al. 1997 \\
\hline D. sapinea & Prunnus persica & Canker \& die-back & Western Cape, SA & Damm et al. 2007 \\
\hline D. sapinea & Pinus patula & Diseased tissues/ Symptomless & $\begin{array}{l}\text { KwaZulu-Natal, Western } \\
\text { Cape, SA }\end{array}$ & $\begin{array}{l}\text { Swart et al. } 1985 \\
\text { Smith et al. } 1996 b\end{array}$ \\
\hline D. sapinea & Pinus radiata & “ & Eastern Cape, Western Cape, SA & $\begin{array}{l}\text { Swart et al. } 1985 \text {; } \\
\text { Smith et al. } 1996 b\end{array}$ \\
\hline D. sapinea & Protea repens & Symptomless & KwaZulu-Natal, SA & Smith et al. $1996 \mathrm{~b}$ \\
\hline D. scrobiculata & Pinus patula & Symptomless/ Die-back & KwaZulu-Natal, Mpumalanga, SA & Bihon et al. $2012 \mathrm{a}$ \\
\hline D. seriata & Malus sp. & Diseased tissues & Western Cape, SA & Slippers et al. 2007 \\
\hline D. seriata & Prunus sarmeniaca & " & Limpopo, SA & Denman et al. 2003 \\
\hline D. seriata & Prunnus persica & “ & Western Cape, SA & Slippers et al. 2007 \\
\hline D. seriata & Prunus salicina & “ & “ & Slippers et al. 2007 \\
\hline D. seriata & Populus sp. & “ & “ & Slippers et al. 2007 \\
\hline D. seriata & Prunus magnifica & Symptomless & “ & Denman et al. 2003 \\
\hline D. seriata & Pyrus communis & Diseased tissues & “ & Slippers et al. 2007 \\
\hline D. seriata & Vitis vinifera & Die-back & “ & Van Niekerk et al. \\
\hline Dothiorella brevicollis & Vachellia karroo & Healthy \& die-back branches & Gauteng, SA & 2004 Jami et al. 2012, \\
\hline Do. capri-amissi & Vachellia erioloba & Not available & Gauteng, Northern Cape, SA & 2015 Slippers et al. \\
\hline Do. dulcispinae & Vachellia karroo & Die-back & “ & 2013 Jami et al. 2012, \\
\hline Do. dulcispinae & Senegalia mellifera & Not available & Namibia & 2015 Slippers et al. \\
\hline Do. oblonga & Senegalia mellifera & “ & Guateng Province, SA & 2013 Slippers et al. \\
\hline Do. pretoriensis & Vachellia karroo & Die-back & Gauteng, SA & 2013 Jami et al. 2012, \\
\hline Do. rosulata & Vachellia karroo & “ & $\begin{array}{l}\text { Northern Cape, SA, Windhoek, } \\
\text { Namibia }\end{array}$ & $\begin{array}{l}2015 \\
\text { Slippers et al. } 2013\end{array}$ \\
\hline Do. rosulata & Senegalia mellifera & “ & Gauteng, Northern Cape, SA & Slippers et al. 2013 \\
\hline Do. rosulata & Vachellia tortilis & “ & Northern Cape, SA & Slippers et al. 2013 \\
\hline Do. viticola & Vachellia karroo & $\begin{array}{l}\text { Healthy leaves, branches } \\
\text { \& die-back }\end{array}$ & Gauteng, SA & Jami et al. 2014 \\
\hline Do. viticola & Senegalia mellifera & Not available & “ & Slippers et al. 2013 \\
\hline Do. viticola & Celtis africana & Healthy branches & “ & Jami et al. 2014 \\
\hline Do. viticola & Gymnosporia buxifolia & “ & “ & Jami et al. 2014 \\
\hline Do. viticola & Prunus persica & Canker \& die-back & Limpopo, SA & Damm et al. 2007 \\
\hline Do. viticola & Podocarpus henkelii & Symptomless & Gauteng, SA & Ndove 2015 \\
\hline Do. viticola & Vitis vinifera & Disease tissue & Western Cape, SA & Van Niekerk et al. \\
\hline $\begin{array}{l}\text { Eutiarosporella } \\
\text { urbis-rosarum }\end{array}$ & Vachellia karroo & Healthy branches & Gauteng, Free state, SA & 2004 Jami et al. 2012 \\
\hline Eu. africana & Celtis africana & “ & Gauteng, SA & Jami et al. 2014 \\
\hline
\end{tabular}




\begin{tabular}{|c|c|c|c|c|}
\hline Fungus & Host & Symptoms/Plant tissue & Sampled area & Reference \\
\hline Eu. graminis & Nestlera sp. & Disease tissue & Free State, SA & Crous et al. 2006 \\
\hline Eu. tritici & Triticum $\mathrm{sp}$ & “ & “ & “ \\
\hline Lasiodiplodia avicenniae & Avicennia marina & Healthy branches & KwaZulu-Natal, SA & Osorio et al. 2017 \\
\hline L euphorbiicola & Adansonia digitata s.l. & Healthy/ Diseased tissues & & Cruywagen et al. 2017 \\
\hline L. bruguierae & Bruguiera gymnorrhiza & Healthy branches & & Osorio et al. 2017 \\
\hline L. crassispora & Pterocarpus angolensis & Diseased tissues & Mpumalanga, SA & Mehl et al. 2011 \\
\hline L. crassispora & Sclerocarya birrea subsp. caffra & & KwaZulu-Natal, SA & \\
\hline L. gilanensis & Podocarpus latifolius & Symptomless & Western Cape, SA & Ndove 2015 \\
\hline L. gonubiensis & Vachellia karroo & “ & “ & Jami et al. 2015 \\
\hline L. gonubiensis & Syzygium cordatum & Canker \& die-back & Eastern Cape, SA & Pavlic et al. 2004, 2007 \\
\hline L. gonubiensis & Bruguiera gymnorrhiza & Healthy branches & KwaZulu-Natal, SA & Osorio et al. 2017 \\
\hline L. gonubiensis & Ceriops tagal & Healthy branches & “ & Osorio et al. 2017 \\
\hline L. gonubiensis & Sclerocarya birrea subsp. caffra & & KwaZulu-Natal, SA & Mehl et al. $2017 b$ \\
\hline L. iraniensis & Sclerocarya birrea subsp. caffra & & KwaZulu-Natal, SA & Mehl et al. 2017b \\
\hline L. mahajangana & Euphorbia ingens & Diseased tissues & Limpopo, SA & $\begin{array}{l}\text { Van der Linde et al. } \\
\quad 2011\end{array}$ \\
\hline L. mahajangana & Adansonia digitata s.l. & Healthy/ Diseased tissues & Limpopo, SA \& Namibia & Cruywagen et al. 2017 \\
\hline L. mahajangana & Sclerocarya birrea subsp. caffra & & Limpopo, SA & Mehl et al. $2017 \mathrm{a}$ \\
\hline L. mahajangana & Magnifera indica & & Limpopo, SA & Mehl et al. $2017 \mathrm{a}$ \\
\hline L. plurivora & Prunus salicina & “ & Western Cape, SA & Damm et al. 2007 \\
\hline L. plurivora & Vitis vinifera & “ & “ & Damm et al. 2007 \\
\hline L. pseudotheobromae & Vachellia karroo & Symptomless & Limpopo, SA & Jami et al. 2015 \\
\hline L. pseudotheobromae & Senegalia mellifera & Not available & Rundu, Namibia & Slippers et al. 2013 \\
\hline L. pseudotheobromae & Pterocarpus angolensis & Healthy/ Diseased tissues & Mpumalanga, SA & Mehl et al. 2011 \\
\hline L. pseudotheobromae & Adansonia digitata s.l. & Healthy/ Diseased tissues & Limpopo, SA & Cruywagen et al. 2017 \\
\hline L. pseudotheobromae & Syzygium cordatum & Symptomless & KwaZulu-Natal, SA & Pillay et al. 2013 \\
\hline L. pseudotheobromae & Terminalia catappa & Die-back & “ & Begoude et al. 2010 \\
\hline L. pseudotheobromae & Terminalia sericea & “ & Namibia & Begoude et al. 2010 \\
\hline L. pseudotheobromae & Sclerocarya birrea subsp. caffra & & Limpopo, SA & Mehl et al. 2017a \\
\hline L. pseudotheobromae & Magnifera indica & & Limpopo, SA & Mehl et al. 2017a \\
\hline L. pyriformis & Senegalia mellifera & Not available & Dordabis, Namibia & Slippers et al. 2013 \\
\hline L. theobromae & Vachellia karroo & Healthy leaves & Gauteng, SA & Jami et al. 2015 \\
\hline L. theobromae & Euphorbia ingens & Diseased tissues & Limpopo, SA & $\begin{array}{l}\text { Van der Linde et al. } \\
\quad 2011\end{array}$ \\
\hline L. theobromae & Barringtonia racemosa & Healthy branches & KwaZulu-Natal, SA & Osorio et al. 2017 \\
\hline L. theobromae & Pterocarpus angolensis & Symptomless & Mpumalanga, SA & Mehl et al. 2011 \\
\hline L. theobromae & Syzygium cordatum & Canker \& die-back & Eastern Cape, SA & Pavlic et al. 2004, 2007 \\
\hline L. theobromae & Terminalia catappa & Die-back & KwaZulu-Natal, SA & Begoude et al. 2010 \\
\hline L. theobromae & Vitis vinifera & “ & Western Cape, SA & Van Niekerk et al. 2004 \\
\hline L. theobromae & Sclerocarya birrea subsp. caffra & & KwaZulu-Natal, SA & Mehl et al. 2017a \\
\hline L. theobromae & Magnifera indica & & Limpopo, SA & Mehl et al. 2017a \\
\hline Neofusicoccum sp.nov1 & Senegalia mellifera & Not available & Rundu, Namibia & Slippers et al. 2013 \\
\hline N. australe & Vachellia karroo & Healthy leaves & Gauteng, SA & Jami et al. 2015 \\
\hline N. australe & Magnifera indica & & Limpopo, SA & Mehl et al. 2017a \\
\hline N. australe & Eucalyptus grandis & Symptomless & KwaZulu-Natal, SA & Pillay et al. 2013 \\
\hline N. australe & Malus domestica & Diseased tissues & Western Cape, SA & Slippers et al. 2007 \\
\hline N. australe & Prunus armeniaca & “ & Limpopo, SA & Denman et al. 2003 \\
\hline$N$. australe & Prunus dulcis & “ & Western Cape, SA & Slippers et al. 2007 \\
\hline N. australe & Prunnus persica & Canker\& die-back & “ & Damm et al. 2007 \\
\hline N. australe & Prunus salicina & Diseased tissues & “ & Slippers et al. 2007 \\
\hline N. australe & Pyrus. communis & “ & " & Slippers et al. 2007 \\
\hline N. australe & Syzygium cordatum & Canker \& die-back & Eastern Cape, SA & Pavlic et al. 2004, 2007 \\
\hline N. australe & Vitis vinifera & Die-back & Western Cape, SA & Van Niekerk et al. 2004 \\
\hline N. australe & Widdringtonia nodiflora & Diseased tissues & “ & Slippers et al. 2005 \\
\hline N. cordaticola & Syzygium cordatum & $\begin{array}{l}\text { Symptomless and dying } \\
\text { branches }\end{array}$ & KwaZulu-Natal, SA & Pavlic et al. 2009 \\
\hline N. cryptoaustrale & Eucalyptus spp. & Symptomless & Gauteng, SA & Maleme 2009 \\
\hline N. crypto-australe & Podocarpus henkelii & Die-back & " & Ndove 2015 \\
\hline N. crypto-australe & Podocarpus latifolius & Symptomless & Western Cape, SA & Ndove 2015 \\
\hline N. crypto-australe & Syzygium cordatum & " & Gauteng, SA & Maleme 2009 \\
\hline$N$. crypto-australe & Bruguiera gymnorrhiza & Healthy branches & KwaZulu-Natal, SA & Osorio et al. 2017 \\
\hline N. crypto-australe & Ceriops tagal & " & " & Osorio et al. 2017 \\
\hline N. crypto-australe & Avicennia marina & “ & KwaZulu-Natal, Eastern Cape, SA & Osorio et al. 2017 \\
\hline N. crypto-australe & Rhizophora mucronata & “ & KwaZulu-Natal, SA & Osorio et al. 2017 \\
\hline N. crypto-australe & Lumnitzera racemosa & “ & “ & Osorio et al. 2017 \\
\hline N. eucalypti & Eucalyptus sp. & “ & Gauteng, SA & Maleme 2009 \\
\hline N. eucalypti & Podocarpus elongatus & Die-back & " & Ndove 2015 \\
\hline
\end{tabular}




\begin{tabular}{|c|c|c|c|c|}
\hline Fungus & Host & Symptoms/Plant tissue & Sampled area & Reference \\
\hline N. eucalypti & Podocarpus henkelii & “ & "6 & Ndove 2015 \\
\hline$N$. eucalypti & Podocarpus latifolius & “ & “ & Ndove 2015 \\
\hline N. eucalyptorum & Eucalyptus grandis & Canker \& die-back & Mpumalanga, SA & Smith et al. 2001 \\
\hline N. eucalyptorum & Eucalyptus nitens & “ & " & Smith et al. 2001 \\
\hline N. eucalyptorum & Eucalyptus sp. & Not available & Western Cape, SA & Slippers et al. 2004 \\
\hline N. kwambonambiense & Afrocarpus falcatus & Die-back & Mpumalanga, SA & Ndove 2015 \\
\hline N. kwambonambiense & Vachellia karroo & Healthy branches \& leaves & Gauteng, SA & Jami et al. 2015 \\
\hline N. kwambonambiense & Celtis africana & Healthy branches & " & Jami et al. 2014 \\
\hline N. kwambonambiense & Eucalyptus grandis & Symptomless & KwaZulu-Natal, SA & Pillay et al. 2013 \\
\hline N. kwambonambiense & Podocarpus henkelii & Die-back & Mpumalanga, SA & Ndove 2015 \\
\hline N. kwambonambiense & Syzygium cordatum & Symptomless & KwaZulu-Natal, SA & Pillay et al. 2013 \\
\hline N. kwambonambiense & Terminalia sericea & Not available & $\mathrm{SA}$ & Begoude et al. 2010 \\
\hline N. kwambonambiense & Bruguiera gymnorrhiza & Healthy branches & KwaZulu-Natal, SA & Osorio et al. 2017 \\
\hline N. kwambonambiense & Rhizophora mucronata & Healthy branches & “ & Osorio et al. 2017 \\
\hline N. kwambonambiense & Magnifera indica & & Limpopo, SA & Mehl et al., 2017a \\
\hline N. luteum & Syzygium cordatum & Canker \& die-back & Eastern Cape, SA & Pavlic et al. 2004, 2007 \\
\hline N. luteum & Avicennia marina & Healthy branches & KwaZulu-Natal, SA & Osorio et al. 2017 \\
\hline$N$. luteum & Bruguiera gymnorrhiza & “ & “ & Osorio et al. 2017 \\
\hline N. luteum & Rhizophora mucronata & “ & KwaZulu-Natal, SA & Osorio et al. 2017 \\
\hline N. mangiferum & Syzygium cordatum & Canker \& die-back & “ & Pavlic et al. 2004, 2007 \\
\hline N. mangiferum & Tibouchina urvilleana & Healthy/ Dead tissues & KwaZulu-Natal, SA & Heath et al. 2011 \\
\hline N. mangroviorum & Avicennia marina & Healthy branches & KwaZulu-Natal, Eastern Cape, SA & \\
\hline N. mangroviorum & Bruguiera gymnorrhiza & “ & “ & \\
\hline N. mangroviorum & Rhizophora mucronata & “ & Eastern Cape, SA & \\
\hline N. mediterraneum & Sclerocarya birrea subsp. caffra & & KwaZulu-Natal, Mpumalanga, SA & Mehl et al. $2017 \mathrm{a}$ \\
\hline N. mediterraneum & Magnifera indica & & Limpopo, SA & Mehl et al. $2017 \mathrm{a}$ \\
\hline N. parvum & Afrocarpus falcatus & Die-back & Mpumalanga, SA & Ndove 2015 \\
\hline N. parvum & Vachellia karroo & Healthy leaves & Gauteng, SA & Jami et al. 2015 \\
\hline N. parvum & Eucalyptus dorrigoensis & Symptomless & “ & Maleme 2009 \\
\hline N. parvum & Eucalyptus grandis & Canker \&die-back & Mpumalanga, SA & $\begin{array}{l}\text { Smith et al. } 2001 \text {; } \\
\text { Slippers et al. } 2004\end{array}$ \\
\hline N. parvum & Eucalyptus microcorvs & Symptomless & Gauteng, SA & Maleme 2009 \\
\hline N. parvum & Eucalyptus nicholii & “ & “ & Maleme 2009 \\
\hline N. parvum & Eucalyptus ovata & “ & “ & Maleme 2009 \\
\hline N. parvum & Eucalyptus robusta & “ & “ & Maleme 2009 \\
\hline N. parvum & Eucalyptus saligna & “ & “ & Maleme 2009 \\
\hline N. parvum & Eucalyptus scoparia & “ & “ & Maleme 2009 \\
\hline N. parvum & Eucalyptus smithii & Canker \& die-back & Mpumalanga, SA & $\begin{array}{l}\text { Smith et al. } 2001 \text {; } \\
\text { Slippers et al. } 2004\end{array}$ \\
\hline N. parvum & Eucalyptus tereticornis & Symptomless & Gauteng, SA & Maleme 2009 \\
\hline N. parvum & Eucalyptus spp. & “ & “ & Maleme 2009 \\
\hline N. parvum & Gymnosporia buxifolia & Healthy branches & “ & Jami et al. 2014 \\
\hline N. parvum & Heteropyxis natalensis & Canker \& die-back & KwaZulu-Natal, SA & Denman et al. 2003 \\
\hline N. parvum & Podocarpus henkelii & Symptomless & Gauteng, SA & Ndove 2015 \\
\hline N. parvum & Schizolobium parahyba & Die-back & “ & Mehl et al. 2014 \\
\hline N. parvum & Syzygium cordatum & Canker \& die-back & Eastern Cape, SA & Pavlic et al. 2004, 2007 \\
\hline N. parvum & Sequoia gigantea & Not available & “ & Slippers et al. 2004 \\
\hline N. parvum & Syzygium guineense & Canker \& die-back & “ & Pavlic et al. 2004, 2007 \\
\hline N. parvum & Terminalia catappa & Die-back & KwaZulu-Natal, SA & Begoude et al. 2010 \\
\hline N. parvum & Terminalia sericea & Not available & SA & Begoude et al. 2010 \\
\hline N. parvum & Tibouchina urvilleana & Healthy/ Dead tissues & " & Heath et al. 2011 \\
\hline N. parvum & Vitis vinifera & Die-back & Western Cape, SA & Van Niekerk et al. 2004 \\
\hline N. parvum & Avicennia marina & Healthy branches & KwaZulu-Natal, Eastern Cape, SA & Osorio et al. 2017 \\
\hline N. parvum & Rhizophora mucronata & “ & Eastern Cape, SA & Osorio et al. 2017 \\
\hline N. parvum & Bruguiera gymnorrhiza & “ & $\begin{array}{l}\text { KwaZulu-Natal, Eastern } \\
\text { Cape, SA }\end{array}$ & Osorio et al. 2017 \\
\hline N. parvum & Lumnitzera racemosa & “ & KwaZulu-Natal, SA & Osorio et al. 2017 \\
\hline N. parvum & Sclerocarya birrea subsp. caffra & & Limpopo, SA & Mehl et al. 2017a \\
\hline N. parvum & Magnifera indica & & Limpopo, SA & Mehl et al. 2017a \\
\hline N. protearum & Vachellia karroo & Symptomless & $\begin{array}{l}\text { Western Cape, Eastern } \\
\text { Cape, SA }\end{array}$ & Jami et al. 2015 \\
\hline N. protearum & Heteropyxis natalensis & Canker \& die-back & Western Cape, SA & Denman et al. 2003 \\
\hline N. protearum & $\begin{array}{l}\text { Leucadendron laureolum } X l \text {. } \\
\text { Salignum }\end{array}$ & “ & “ & Denman et al. 2003 \\
\hline N. protearum & Protea cynaroides & Die-back & “ & Denman et al. 2003 \\
\hline N. protearum & Prtoea eximia & Canker & “ & Denman et al. 2003 \\
\hline N. protearum & Protea magnifica & Canker \& Leaf necrosis & “ & Denman et al. 2003 \\
\hline
\end{tabular}




\begin{tabular}{|c|c|c|c|c|}
\hline Fungus & Host & Symptoms/Plant tissue & Sampled area & Reference \\
\hline N. protearum & Protea repens & Canker & “ & Denman et al. 2003 \\
\hline N. umdonicola & Syzygium cordatum & Canker \& die-back & Eastern Cape, SA & Pavlic et al. 2004, 2007 \\
\hline N. umdonicola & Avicennia marina & Healthy branches & KwaZulu-Natal, SA & Osorio et al. 2017 \\
\hline N. umdonicola & Bruguiera gymnorrhiza & " & KwaZulu-Natal, Eastern Cape, SA & Osorio et al. 2017 \\
\hline N. umdonicola & Lumnitzera racemosa & “ & KwaZulu-Natal, SA & Osorio et al. 2017 \\
\hline N. umdonicola & Magnifera indica & & Limpopo, SA & Mehl et al. 2017a \\
\hline N. ursorum & Eucalyptus spp. & Symptomless & Gauteng, SA & Maleme 2009 \\
\hline N. ursorum & Podocarpus henkelii & " & " & Ndove 2015 \\
\hline N. viticlavatum & Vitis vinifera & Die-back & Western Cape, SA & Van Niekerk et al. \\
\hline$N$. vitifusiforme & Vachellia karroo & Healthy branches \& leaves & Gauteng, SA & 2004 Jami et al. 2015 \\
\hline$N$. vitifusiforme & Acacia mearnsii & Not available & SA & Van der Linde 2010 \\
\hline$N$. vitifusiforme & Prunnus persica & Canker \& die-back & Western Cape, SA & Damm et al. 2007 \\
\hline$N$. vitifusiforme & Prunus salicina & “ & “ & Damm et al. $2007 \mathrm{Mehl}$ \\
\hline$N$. vitifusiforme & Schizolobium parahyba & Die-back & Gauteng, Mpumalanga, SA & et al. 2014 \\
\hline$N$. vitifusiforme & Vitis vinifera & “ & Western Cape, SA & Van Niekerk et al. \\
\hline$N$. vitifusiforme & Sclerocarya birrea subsp. caffra & & KwaZulu-Natal, Mpumalanga, SA & 2004 Mehl et al. 2017a \\
\hline Neofusicoccum sp.nov2 & Afrocarpus falcatus & Die-back & Gauteng, SA & Ndove 2015 \\
\hline Neofusicoccum sp.nov2 & Podocarpus henkelii & “ & Mpumalanga, SA & Ndove 2015 \\
\hline $\begin{array}{l}\text { Oblongocollomyces } \\
\text { variabilis }\end{array}$ & Vachellia hebeclada & Not available & Windhoek, Namibia & Slippers et al. 2013 \\
\hline $\begin{array}{l}\text { Oblongocollomyces } \\
\text { variabilis }\end{array}$ & Vachellia karroo & Healthy branches & Gauteng, SA & Jami et al. 2015 \\
\hline $\begin{array}{l}\text { Oblongocollomyces } \\
\text { variabilis }\end{array}$ & Senegalia mellifera & Not available & Northern Cape, SA & Slippers et al. 2013 \\
\hline $\begin{array}{l}\text { Pseudofusicoccum } \\
\text { olivaceum }\end{array}$ & Magnifera indica & & Limpopo, SA & Mehl et al. 2017a \\
\hline Ps. violaceum & Pterocarpus angolensis & “ & " & Mehl et al. 2011 \\
\hline Ps. olivaceum & Pterocarpus angolensis & Symptomless & Mpumalanga, SA & Mehl et al. 2011 \\
\hline Saccharata proteae & Protea cynaroides & " & Western Cape, SA & Denman et al. 2003 \\
\hline Sa.proteae & Protea repens & Leaf necrosis & “ & Denman et al. 2003 Van \\
\hline Sphaeropsis porosa & Vitis vinifera & “ & “ & Niekerk et al. 2004 \\
\hline
\end{tabular}




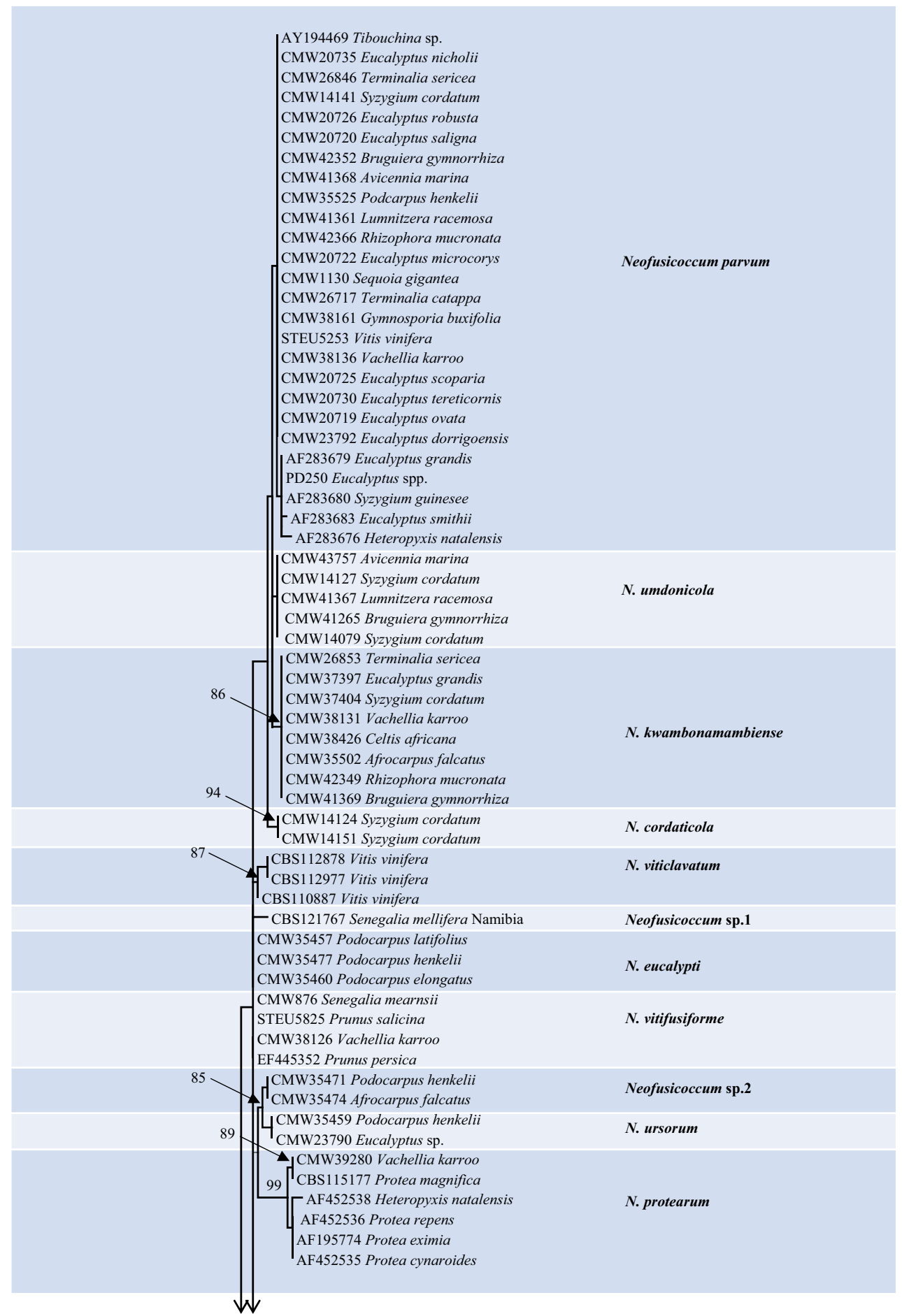




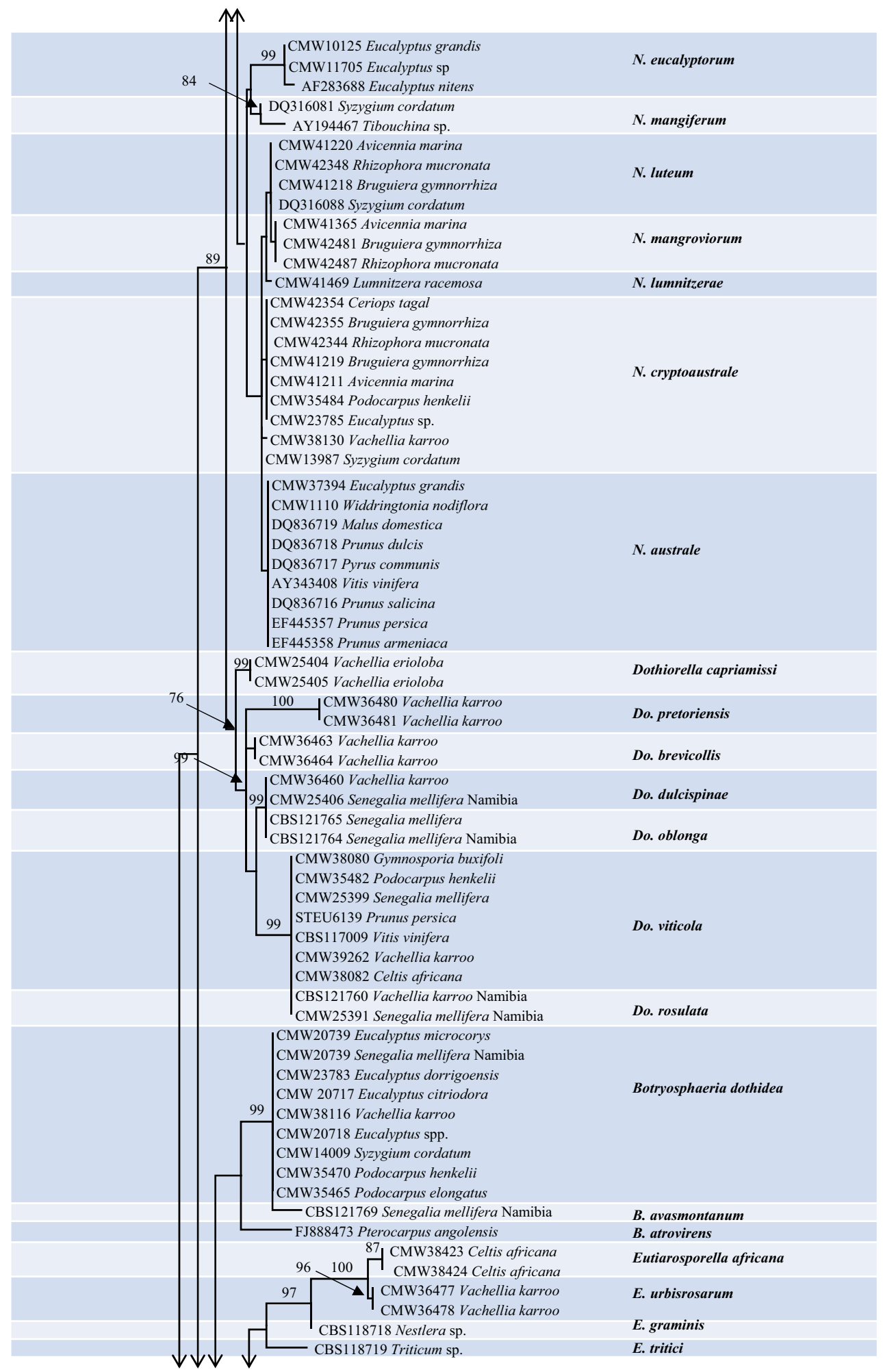




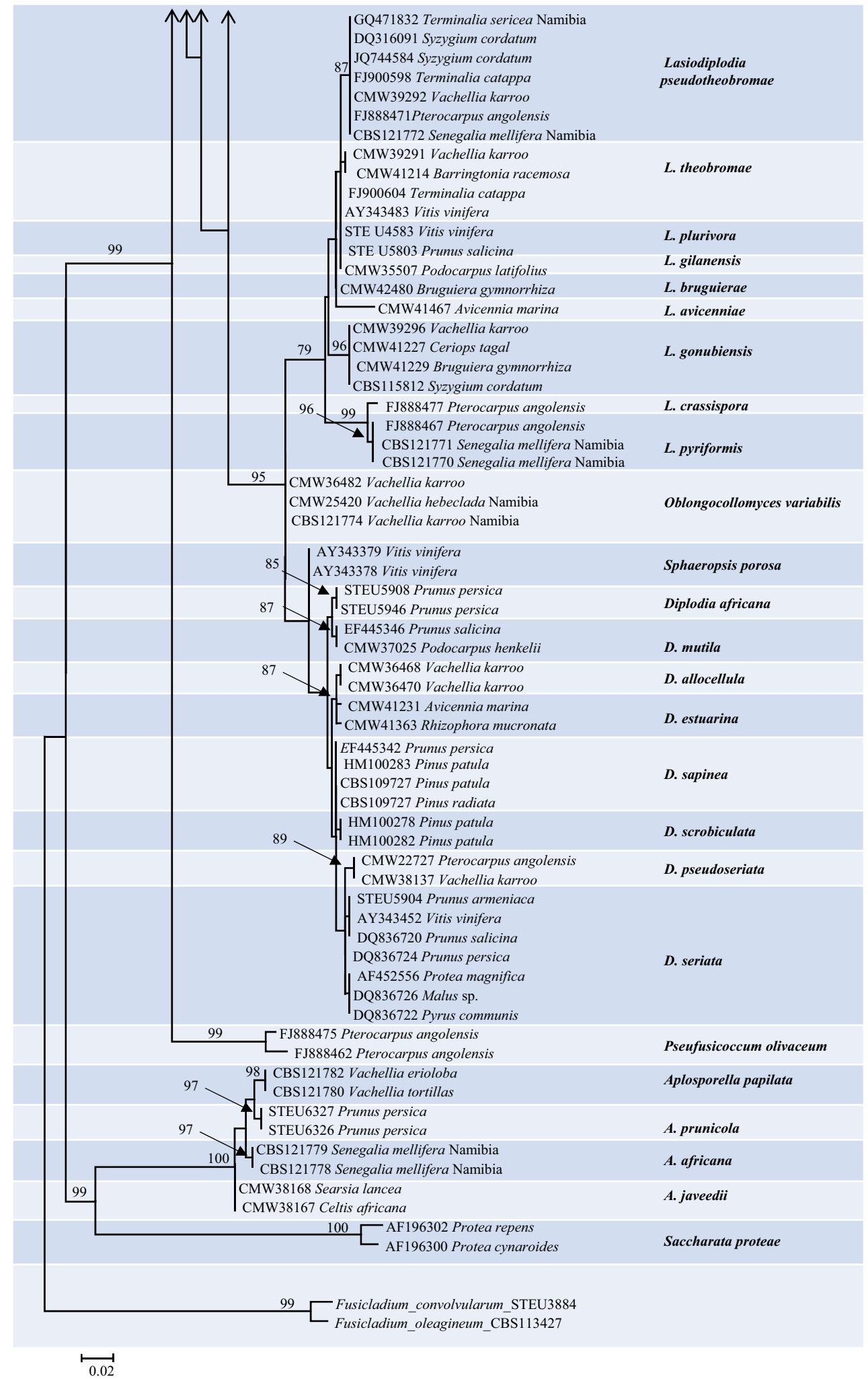

Fig. 1 Maximum Likelihood (ML) tree of ITS ribosomal DNA of Botryosphaeriales. Bootstrap values above 70\% are given at the nodes. The tree was rooted to Fusicladium convolvularum and F. oleagineum (STEU3884 and CBS113427) 


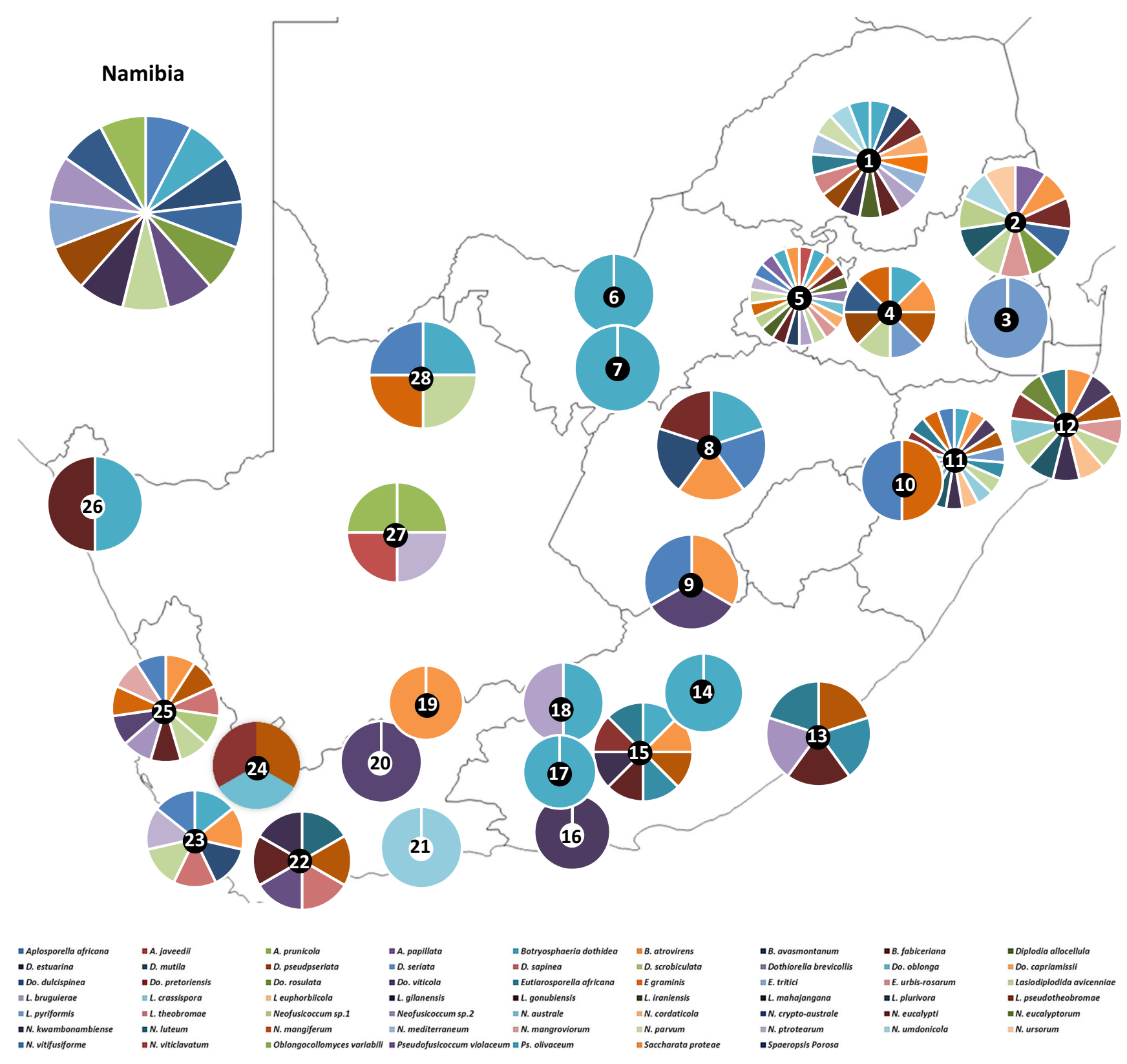

Fig. 2 Diversity of Botryosphaeriales species in each published site in South Africa and Namibia. *South African sites in the map: 1 = Limpopo, Mokopane, Tzaneen (Limpopo Province); 2 = Sabie, Pretoriuskop (Mpumalanga Province), Phalaborwa (Limpopo Province); 3 = Bracken Hill (Swaziland); $4=$ Mpumalanga, Piet Retief (Mpumalanga Province); $5=$ Pretoria (Gauteng Province), Tweefontein (Mpumalanga Province), Modimolle (Limpopo Province); $6=$ Delareyville (North West Province); $7=$ Bloemhof (North West Province); $8=$ Bloemfontein (Free State Provincce); $9=$ Aliwal North (Eastern Cape Province); 10 = Wasbank (KwaZulu-Natal Province); $11=$ KwaZulu-Natal Province; $12=\mathrm{R}$ i c h a r d s Bay, Mkuze, Kwambonambi, Kosi Bay, Sodwana Bay (KwaZulu-Natal Province); 13 = Haga Haga, East London (Eastern Cape Province); 14 = Queenstown (Eastern Cape Province); 15 = Eastern Cape Province; 16 = Humansdorp (Eastern Cape Province); 17 = Jansenville (Eastern Cape Province); 18 = Graaff-Reinet (Eastern Cape Province); $19=$ Beaufort West (Western Cape Province); 20 = Calitzdorp, Buffelskloof (Western Cape Province); 21 = George (Western Cape Province); 22 = Hermanus, Elgine, Jonkershoek (Western Cape Province); 23 = Cape Town (Western Cape Province); 24 = Western Cape Province; 25 = Ceres, Swellendam, Robertson (Western Cape Province); $26=$ Hondeklip Bay (Northern Cape Province); $27=$ Prieska (Northern Cape Province); 28 = Kuruman, Augrabies, Upington (Northern Cape Province) 
richness and distribution, an important objective was to consider knowledge gaps, particularly those relating to geographical distribution and host range.
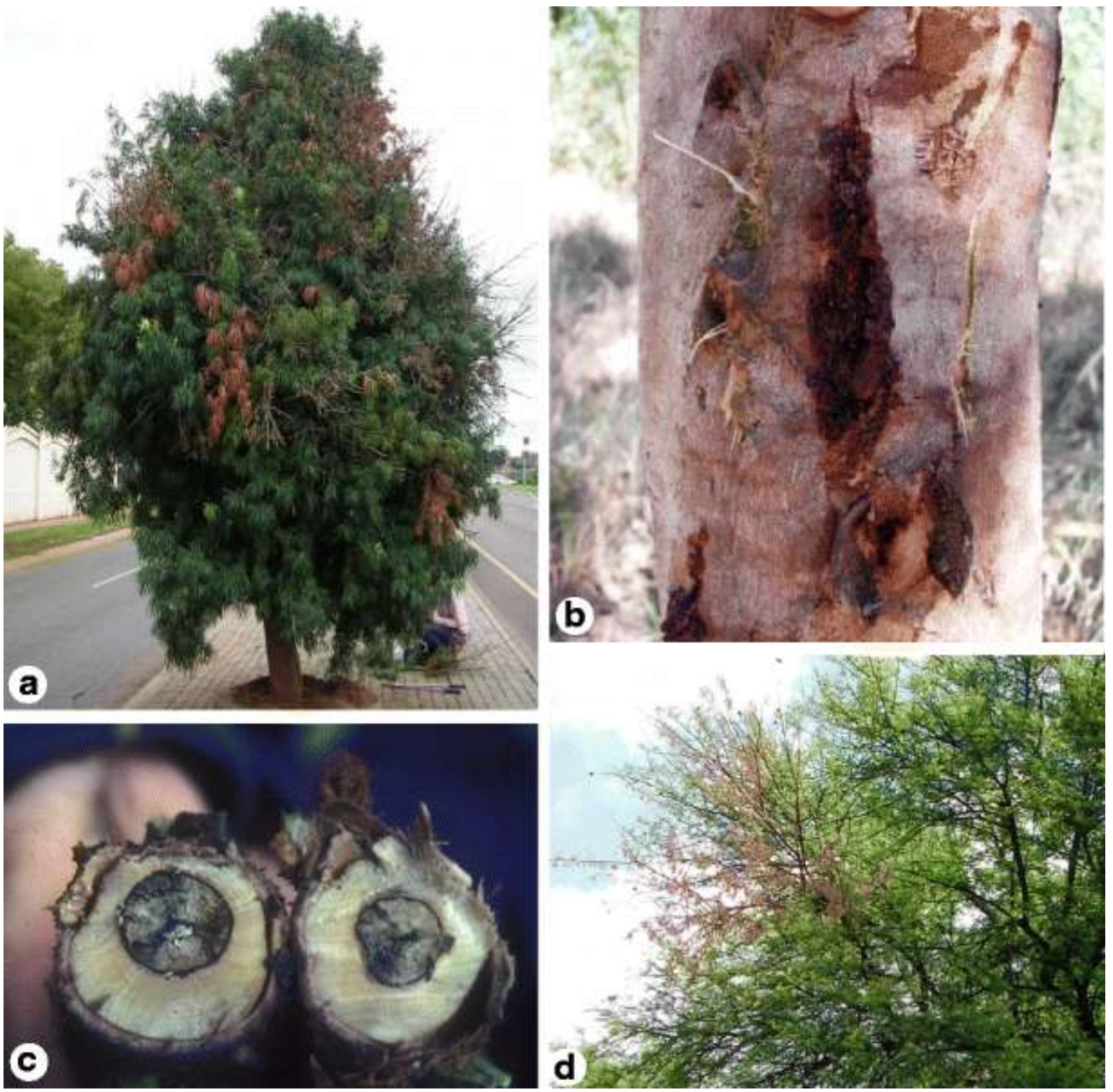

Fig. 3. Symptoms causes by Botryosphaeriales species, A. Dieback on Podocarpus sp. (Ndove 2015). B, C. Canker and pith discoloration on a Eucalyptus stem and branches (Slippers et al. 2009). D. Die-back on Vachellia (Acacia) karroo (Jami et al. 2013) 


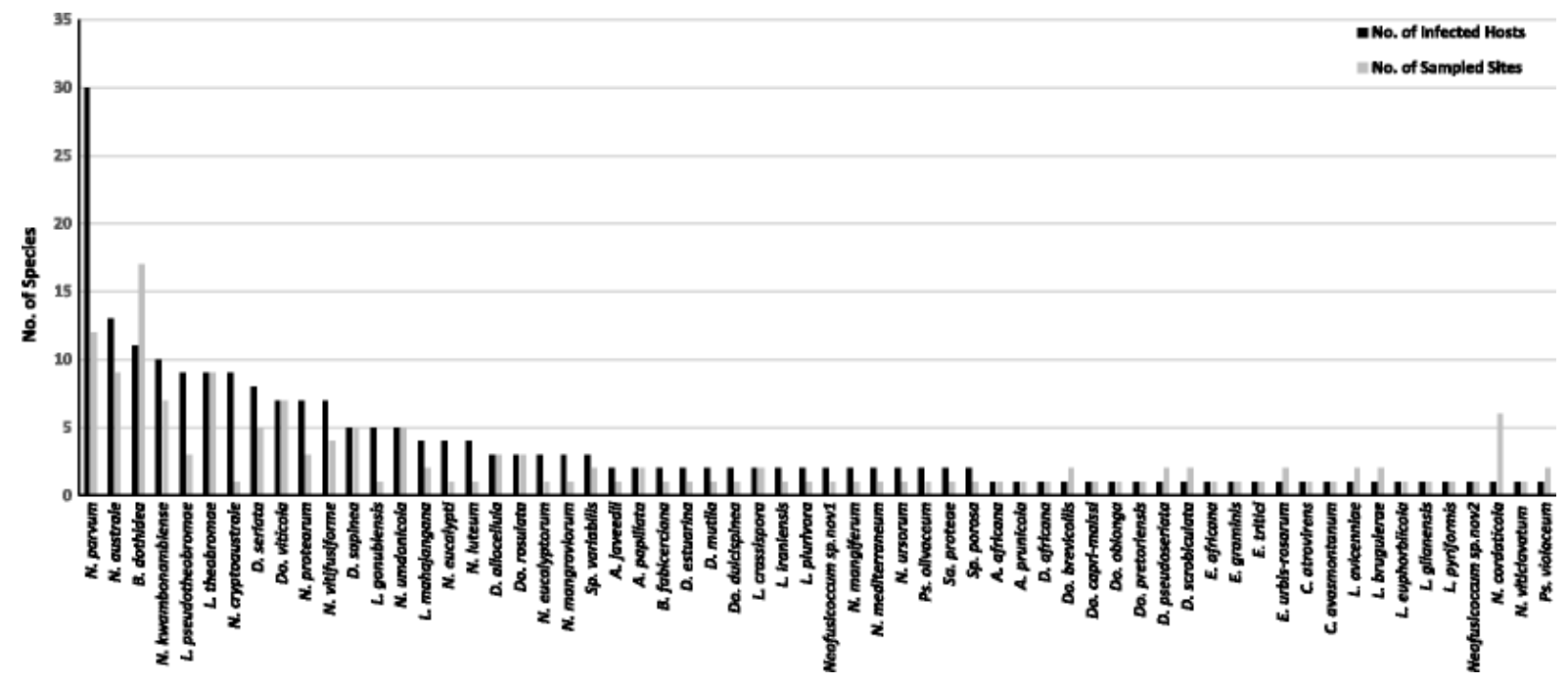

Fig. 4. Frequency of Botryosphaeriales species and number of sampled sites (per species) from all previous published studies across South Africa and Namibia on various hosts. Pie charts illustrate the species diversity in each sampled site

\section{Botryosphaeriales associated with native trees}

A number of relatively intensive studies have been completed on Botryosphaeriales on native trees in South Africa and Namibia. In total, 52 Botryosphaeriales species have been characterised from both symptomatic and asymptomatic tissues on 32 native tree species studied in these two countries (Marincowitz et al. 2008; Denman et al. 2003; Begoude et al. 2010; Mehl et al. 2011; Van der Linde et al. 2011; Ndove 2015; Jami et al. 2012, 2013, 2014, 2015; Swart 1986; Osorio et al. 2017; Mehl et al. 2017a; Cruywagen et al. 2017). Of these, 18 species were isolated from Vachellia (Acacia) species (Jami et al. 2012, 2013, 2014, 2015; Slippers et al. 2014), 14 species were from mangrove trees (Osorio et al. 2017), 12 species from Syzygium cordatum (Pavlic et al. 2007), 12 species from Sclerocarya birrea subsp. caffra (Mehl et al. 2017a), 11 species from A. mellifera (Slippers et al. 2014), and nine species from Adansonia digitata s.I (Cruywagen et al. 2017) and Podocarpus spp. (Ndove 2015) (Table 1).

Canker and die-back are typical symptoms of diseases caused by Botryosphaeriales that have commonly been reported from native trees in South Africa. These, however, received little attention until 2004 when the South African government funded an initiative (Centre of Excellence in Tree Health Biotechnology) to specifically study the health of native trees (Steenkamp and Wingfield 2013). Nineteen species of the Botryosphaeriales have been reported from diseased tissue taken from native trees in South Africa and Namibia (Table 1), although some might have been associated as secondary pathogens or as saprophytic colonists of the dead tissue. Some species such as Neofusicoccum parvum are common and well-known pathogens on numerous hosts, but are also common endophytes existing asymptomatically in many of these studies. Six species on native and non-native hosts that are important include $B$. dothidea, Lasiodiplodia theobromae, $N$. australe, $N$. parvum, $N$. kwambonambiense and Dothiorella viticola. These species were particularly common in studies and have been found in both healthy and diseased tissues. 
The role of many of Botryosphaeriales species in causing diseases is not known. In those cases where inoculation studies have been conducted, species vary in their pathogenicity (Slippers et al. 2017). Given this uncertainty, we consider all the species described from native plants in this section as potential pathogens. On native hosts, inoculation studies with Botryosphaeriales have been conducted only on Avicennia marina, Bruguiera gymnorrhiza, Euphorbia ingens, Pterocarpus angolensis, Podocarpus henkelii, S. cordatum and Vachellia (Acacia) karroo (Pavlic et al. 2007; Mehl et al. 2011; Jami et al. 2013, 2015; Ndove 2015; Osorio et al. 2017; Van der Linde et al. 2011). These studies have shown all the inoculated species were capable of causing lesions. Although they might be considered as potential pathogens, their epidemiology, particularly under natural conditions remains to be understood. Some produced very small lesions and could play a minor or no role in disease development. The most aggressive species across these studies were $N$. mangiferae on $S$. cordatum (Pavlic et al. 2007), Lasiodiplodia pseudotheobromae on Pterocarpus (Mehl et al. 2011), L. theobromae, N. australe, N. parvum, Sphaeropsis variabilis on V. karroo (Jami et al. 2015) and Neofusicoccum sp. nov. 2 on Pt. henkelii (Ndove 2015) and L. avicenniae on A. marina (Osorio et al. 2017).

\section{Botryosphaeriales associated with plantation-grown trees}

The Botryosphaeriales pose an important threat to the productivity of South African forestry. The commercial forestry area in the country includes approximately 1.3 million ha, of which 671,000 ha is planted with pine species (mainly Pinus patula, P. elliottii, P. taeda), 516,407 ha with eucalypts (mostly Eucalyptus grandis or derived hybrids and clones) and 100,606 ha with wattle (Acacia mearnsii) (Geldenhuys 1997; Http://www.forestry.co.za/statistical-data/ 2011). These plantations are important sources of structural timber, fuel wood, pulpwood and resin as well as providing employment for large numbers of South Africans. Diseases associated with Botryosphaeriales are prominent on all the genera deployed by the South African forestry industry and in some cases have contributed significantly to shaping the industry (Swart and Wingfield 1991). There is no significant forestry industry in Namibia and consequently, these fungi are not relevant in terms of commercial tree planting.

Diplodia sapinea is one of the most important die-back and canker pathogens on pine species worldwide, and this is especially true in South Africa (Swart and Wingfield 1991). The pathogen is particularly important due to its common occurrence, and latent, opportunistic nature of infection (Flowers et al. 2003; Stanosz and Carlson 1996). In infected areas, which include most of South Africa were Pinus spp. are planted, this pathogen exists almost ubiquitously within healthy Pinus trees as an endophyte (Bihon et al. 2011). When the trees are weakened through wounding by hail, or due to drought or other forms of stress, die-back can be very rapid and dramatic (Swart and Wingfield 1991; Zwolinski et al. 1995; Zwolinski et al. 1990). For example, P. radiata is a preferred forestry species, but is also one of the most susceptible Pinus species to $D$. sapinea, and it is consequently no longer planted in large areas in South Africa where hail is common (Swart and Wingfield 1991; Smith et al. 1996b).

Diplodia sapinea was introduced into South Africa together with its pine hosts (Swart et al. 1985; Burgess and Wingfield 2002). A number of studies have shown that $D$. sapinea 
populations are highly diverse and must have been introduced many times (Bihon et al. 2012a; Bihon et al. 2012b; Burgess et al. 2004b; Smith et al. 2000). Bihon et al. (2012b) showed this introduction is unlikely to have been predominantly by seed, and it must consequently have been through seedling imports or other routes. Subsequent spread within the country has been horizontal between established plants, and mostly via rainsplash and wind over relatively short distances (Úrbez-Torres et al. 2010; Epstein et al. 2008; Swart et al. 1987). A cryptic sister species, D. scrobiculata, has been reported only once from South Africa, but appears to be rare in comparison to the commonly occurring $D$. sapinea (Burgess et al. 2004a; Bihon et al. 2010).

The Botryosphaeriales have been well studied on Eucalyptus spp. in many parts of the world, including South Africa (Maleme 2009; Pillay et al. 2013; Slippers et al. 2004; Smith et al. 1996a; Pavlic et al. 2007; Smith et al. 1994), Australia (Burgess et al. 2006; Slippers et al. 2004; Taylor et al. 2009), Chile (Ahumada 2003), China (Chen et al. 2011), Colombia (Rodas et al. 2009), Congo (Roux et al. 2000), New Zealand (Billones-Baaijens et al. 2012), Portugal (Barradas et al. 2016), Spain (Iturritxa et al. 2011), Uganda (Nakabonge 2002), Uruguay (Pérez et al. 2008; Pérez et al. 2009) and Venezuela (Mohali et al. 2007). By 2009, at least 23 species of these fungi had been recorded from Eucalyptus in different countries of the world (Slippers et al. 2009). Of these, eight species have been found on Eucalyptus spp. in South Africa and many of these have been isolated from diseased plant tissue. For example, $N$. australe, N. eucalyptorum, N. eucalypticola, N. parvum, and N. kwambonambiense have been identified from die-back and stem cankers in South Africa (Maleme 2009; Slippers et al. 2004; Smith et al. 1996a). Other than N. australe, the remaining species are commonly present on Eucalyptus in South Africa (Slippers et al. 2009; Pillay et al. 2013).

Several Botryosphaeriales species, including L. theobromae, B. dothidea and Diplodia spp., have been identified from both symptomatic and asymptomatic $A$. mearnsii in South Africa (Roux et al. 1997; Gibson 1975). More recent studies have also revealed the presence of a Dothiorella sp. (Synonym: Spencermartinsia sp.) (Slippers et al. 2014), N. australe, N. vitifusiforme and Sphaeropsis variabilis on A. mearnsii in South Africa (Van der Linde et al. 2010). Pathogenicity trials have shown that $B$. dothidea and $N$. australe can be important pathogens on A. mearnsii (Roux 1998; Van der Linde et al. 2010).

\section{Botryosphaeriales associated with fruit and ornamental trees}

Botryosphaeriales are important pathogens of fruit trees. They cause disease symptoms on various plant tissues such as die-back and canker of branches and twigs, leaf necrosis, and post-harvest fruit decay. Namibia does not have a significant fruit industry and consequently there are no studies reported from that country. However, various fruit trees in South Africa are affected (Table 1), including almond, apple, apricot, avocado, citrus, mango, nectarine, peach, pear, plum and prune (Slippers et al. 2007; Damm et al. 2007; Martínez-Minaya et al. 2015; Crous et al. 2000), as well as grapevine that have been well studied in South Africa (Fourie and Halleen 2001; Van Niekerk et al. 2004, 2006, 2010a, b, 2011). Eleven species of Botryosphaeriales have been identified from grapevines and 18 species from the other fruit trees in South Africa. Among these species, N. australe and D. seriata are the most commonly encountered species on stone fruits. All of the identified species have been shown to produce significant lesions in inoculation trials and are considered as potential 
pathogens, but Do. viticola is considered less pathogenic than the other species on fruit trees (Damm et al. 2007).

Botryosphaeriales species are associated with the die-back of ornamental trees such as Schizolobium parahyba and Terminalia catappa in South Africa (Begoude et al. 2010; Mehl et al. 2014). Three Botryosphaeriales species have been identified on these trees, of which $N$. parvum is the most common species. It is important to recognize that the capacity to colonize wood may not always be directly correlated with the ability to cause symptoms such as decline and die-back. This should be more thoroughly explored in future studies.

\section{Host and geographical structure}

The numbers of species of Botryosphaeriales known from a variety of hosts in South Africa and Namibia has grown significantly in recent years. Here we consider these reports to characterize patterns of host and geographic distribution for this group of fungi in southern Africa.

\section{Host associations}

Of the 62 Botryosphaeriales species isolated from 66 hosts during the course of the last decade in South Africa and Namibia (Table 1; Fig. 1), 12 have been described as new taxa from non-native hosts and 27 as new from native hosts (Table 1) (Maleme 2009; Pavlic et al. 2004; Denman et al. 2003; Jami et al. 2012, 2014, 2015; Mehl et al. 2014; Osorio et al. 2017). Eleven of the Botryosphaeriales species have been isolated from both native and non-native trees in the region, and these represent species with an almost cosmopolitan distribution and very broad host ranges (Fig. 1, Table 1).

The number of hosts from which each Botryosphaeriales species has been reported varies significantly. Many species are apparently rare and have been isolated only in low numbers. Their host records might thus be influenced by their rare occurrence, and not necessarily provide a true reflection of their ability to infect other plants. Thirteen Botryosphaeriales species have been isolated from only two hosts, and 22 species have been isolated from more than three hosts in South Africa and Namibia. Neofusicoccum parvum has been isolated from 30 hosts (14 natives, 16 non-natives) and shows the highest host diversity in South Africa and Namibia. Neofusicoccum australe and $B$. dothidea are the next most commonly encountered species, and have been reported from 13 (three natives, nine nonnatives) and nine (five natives, four non-natives) different hosts, respectively (Table 1). Interestingly, $N$. parvum and $N$. australe have been found on greater numbers of non-native than native plants in South Africa and Namibia (Table 1).

Of the 66 host plants considered in South Africa and Namibia, 24 were infected with only one species of Botryosphaeriales while the remaining tree species were hosts to more than one species (Fig. 4). Vachellia karroo as host to 18 Botryosphaeriales species had the highest diversity of these fungi in South Africa and Namibia (Slippers et al. 2014; Jami et al. 2015). Podocarpus henkelii (Ndove 2015), Vitis vinifera (Van Niekerk et al. 2004), S. cordatum (Pavlic et al. 2007; Pavlic et al. 2004), Sclerocarya birrea subsp. caffra (Mehl et al. 2017a) and mangrove trees (Osorio et al. 2017) have also yielded a high diversity of these fungi, 
ranging from 9 to 14 species each. While these data are interesting, they should be viewed against a background of a greater intensity and breadth of geographical sampling of these hosts compared to others in the region. The data illustrate the extent to which a host plant can be infected by multiple species of Botryosphaeriales. For example, Jami et al. (2015) showed that various species of Botryosphaeria, Dothiorella and Neofusicoccum frequently co-occur on V. karroo across South Africa, with ranging from 1 to 8 species per site. If sampled more intensively, the same pattern might be expected for other hosts.

\section{Species distribution}

The Botryosphaeriales occur throughout southern Africa. While some species occur fairly broadly, others appear to have a limited geographic distribution. It is necessary to be cautious not to over interpret the results of studies conducted thus far because obvious gaps clearly still exist. But the record of occurrence is becoming sufficiently complete to begin to understand some of the emerging patterns of diversity of the Botryosphaeriales. Also to consider how these might be related to climate or other factors shaping their distribution (Mehl et al. 2017a).

Botryosphaeria dothidea is one of the most widespread Botryosphaeriales species in the world (Marsberg et al. 2017) and it has been found from 17 sites in different parts of South Africa and Namibia (Fig. 2). This species has been found across parts of these countries with climates ranging from Mediterranean, to continental to sub-tropical as well as very dry and desert-like (Http://en.wikipedia.org/wiki/Climate_of_South_Africa 2007; Conradie 2012). This is perhaps not surprising given that recent studies have shown that $B$. dothidea can survive and grow effectively at a broad range of temperatures and its pycnidia appear to be long-lived and produce conidia for at least 6 years (Urbez-Torres et al. 2010; Copes and Hendrix 2004; Michailides and Morgan 1992). As with other species of the Botryosphaeriales, rain and wind play an important role in spreading $B$. dothidea, which limits the distance of its distribution. The broad host range, however, would mean that it has a more or less continuous distribution of potential hosts that would make migration between regions possible (Ahimera et al. 2004; van Niekerk et al. 2010b).

Neofusicoccum parvum is the second most widespread species, being reported from 12 sites across South Africa (Fig. 2). This fungus has the widest global distribution and host range and it is one of the most pathogenic Botryosphaeriales on woody plants (Slippers and Wingfield 2007). Neofusicoccum parvum has been absent from samples collected in the south-western parts of South Africa. It is unlikely that this is host related, because plants such as $V$. karoo sampled in that part of the country are infected by this fungus in other regions (Jami et al. 2015). It is possible that this distribution is weather related, as this is also the driest part of the country (Conradie 2012). Conversely, it is also one of the least sampled areas of the country, which might also have influenced this observed pattern.

Neofusicoccum australe has been reported from 10 countries and 46 hosts and is particularly common in the southwestern parts of Western Australia (Sakalidis et al. 2011; Burgess et al. 2006; Taylor et al. 2009). This species is also one of the dominant Botryosphaeriales in South Africa. It is the most widespread species in the country after $B$. dothidea and N. parvum, having been reported from nine areas (Fig. 2). This species has 
been found in both desert and temperate areas of South Africa. In parts of Western Australia, it is common in areas with a Mediterranean climate, with hot and dry summers and cool wet winters (Burgess et al. 2006; Cunnington et al. 2007; Taylor et al. 2009).

Lasiodiplodia theobromae is an important species in South Africa (Fig. 2). This fungus has a wide host range both as endophyte and pathogen (Slippers and Wingfield 2007). It has a world-wide distribution (Punithalingam 1976) and has been reported on more than 500 hosts (Punithalingam 1980), although many of these host reports might refer to cryptic sister species in L. theobromae sensu lato (Swart 1986; Phillips et al. 2013). Recent studies in South Africa have shown that $L$. theobromae occurs mostly in the northern and western parts of the country (Fig. 2), and not in central and eastern parts (Mehl et al. 2011; Begoude et al. 2010; Pavlic et al. 2007; Van Niekerk et al. 2004; Jami et al. 2015). These patterns are likely due to climate as $L$. theobromae is known to be confined, or most common, in tropical to sub-tropical climates (Mehl et al. 2017a).

A number of recent studies illustrate a high level of anthropogenic movement of Botryosphaeriales species around the world (Pavlic et al. 2009; Slippers 2003; Slippers and Wingfield 2007; Sakalidis et al. 2013; Marsberg et al. 2017). For example, N. parvum has been reported from 29 countries on 90 hosts (Sakalidis et al. 2013), B. dothidea reported from 24 host genera (representing 17 families) and 18 countries and both species exist across six continents (Marsberg et al. 2017). This result suggests strongly that movement of N. parvum has been human-mediated irrespective of whether it has been moved from native to non-native hosts or vice-versa. Similarly, $D$. sapinea, L. theobromae and $N$. australe, which are commonly reported in South Africa, have more or less cosmopolitan distributions, and have most likely been moved by humans. The results of studies in South Africa illustrate how widely such species can spread once introduced into a country, including into remote and fairly undeveloped regions such as the Northern Cape (Fig. 2). Unfortunately, this also illustrates the fact that current quarantine measures are entirely unable to restrain the global movement of latent pathogens such as the Botryosphaeriales (Burgess et al. 2016).

\section{Conclusions}

During the last two decades, focused studies on the Botryosphaeriales have revealed 38 new species and genera from South Africa and Namibia. Increasing numbers are also being described as surveys are expanded to new areas and hosts. These fungi have been isolated from a wide range disease symptom on important native and non-native trees in southern Africa. Many species have also been isolated from healthy plant tissues. Whether isolated from healthy or diseased tissue, all the species that have been tested in inoculation trials have been shown to induce lesions and are thus considered to have some degree of pathogenicity. However, studies have also revealed that the pathogenicity for different species is variable and it varies between hosts. There is a clear need to characterize the interaction between Botryosphaeriales species, hosts and disease and studies focused on these questions should be encouraged.

The greatest species diversity for the Botryosphaeriales has been observed in the Western Cape Province of South Africa with 17 different species occurring there (Fig. 2). The lowest 
diversity is currently known from the Northern Cape Province (Fig. 2). This might be related to the number of studies in these areas, where most have focused on the Western Cape or the eastern to north-eastern coast of South Africa, and fewer have been done in central or north-western areas. It could also be associated with the greater plant diversity and density in the Western Cape, compared to, for example, the Northern Cape, as well as the harsher (drier) weather conditions in the latter region. However, recent studies on V. karroo in South Africa (Jami et al. 2015) showed that the species diversity was higher in the Tshwane Metropolitan Area than elsewhere in South Africa, even after correcting for sampling intensity. It is not clear what drives this increased diversity, but one possibility is that the higher plant diversity in the urban areas that arised via introductions for horticulture. This, together with the higher frequency of trade (with Pretoria as one of the main urban centres in the country), and compared to other sampled sites could influence the surrounding diversity in Botryosphaeriales. Other factors, such as the intensive human activities, pollution and physical damage to name just a few possibilities could also influence this pattern of diversity.

The application of molecular tools and particularly DNA sequence based analyses has revolutionized the identification of species in the Botryosphaeriales (also see a summary in Slippers et al. 2017). The emerging data has led to a complete revision of the taxonomy of the group including a clear need to re-evaluate previous reports of species, distributions, host associations and other factors relevant to understanding the processes influencing biodiversity patterns. The new technologies have also led to the discovery of a large diversity of species, and new insights into its distribution and host associations. This is especially true in South Africa and Namibia where these fungi have been sampled at least as much, or even more intensively, than in many other parts of the world. No hybrid species have been reported in the region yet, but as Cruywagen et al. (2017) and Rodríguez-Gálvez et al. (2017) have recently shown that this needs to be considered for the Botryosphaeriales and in particular for Lasiodiplodia spp.

All the records considered in this review are based on isolations of fungi in culture. It is well known today that many of endophytic fungi either do not grow well in culture, or are easily overlooked because they grow more slowly than other common endophytes. Making isolations is also time consuming and often not practiced with sufficient rigor. An emerging solution to this problem is to use the high-throughput, culture independent and barcoding based approaches of next generation sequencing (Kemler et al. 2013). Such studies will likely be used in the future to map the distribution of Botryosphaeriales across regions and different hosts more accurately.

The Botryosphaeriales result in asymptomatic infections in their hosts and those species that cause disease usually do so after the onset of stress (Slippers and Wingfield 2007). These fungi clearly form an important natural component of the microbiome, particularly of woody plants. This is sometimes referred to as part of the "second genome" (Zenni et al. 2016). The consequence is that these fungi can easily be accidentally moved to new evironments through trade in plants and plant products, including for example fruit (Crous et al. 2016; Burgess and Wingfield 2017). Once they have been introduced into new environments and particularly given the wide host ranges of many species, they are able to infect new hosts via host shifts or range expansions (Slippers et al. 2005; Crous et al. 2012). 
It is consequently reasonable to expect that they will be increasingly important as pathogens of woodly plants in the future, both in Southern Africa but also globally.

\section{Acknowledgements}

We thank members of the Tree Protection Cooperative Programme (TPCP), the DST/NRF Centre of Excellence in Tree Health Biotechnology (CTHB) and the University of Pretoria, South Africa for financial support.

\section{References}

Ahimera N, Gisler S, Morgan DP, Michailides TJ (2004) Effects of single-drop impactions and natural and simulated rains on the dispersal of Botryosphaeria dothidea conidia.

Phytopathology 94: 1189-1197

Ahumada R (2003) Pathogens in commercial Eucalyptus plantations in Chile, with special reference to Mycosphaerella and Botryosphaeria species. University of Pretoria, Pretoria, South Africa, M.Sc. Thesis

Barradas C, Phillips AJ, Correia A,Diogo E, Bragança H, Alves A(2016) Diversity and potential impact of Botryosphaeriaceae species associated with Eucalyptus globulus plantations in Portugal. Eur J Plant Pathol 146:245-257

Begoude BAD, Slippers B, Wingfield MJ, Roux J (2010) Botryosphaeriaceae associated with Terminalia catappa in Cameroon, South Africa and Madagascar. Mycol Prog 9:101-123

Bihon W, Slippers B, Burgess T, Wingfield M, Wingfield B (2010) Diplodia scrobiculat a found in the southern hemisphere. For Pathol 41:175-181

Bihon W, Slippers B, Burgess T, Wingfield M, Wingfield B (2011) Sources of Diplodia pinea endophytic infections in Pinus patula and P. radiata seedlings in South Africa. For Pathol 41:370-375

Bihon W, Burgess T, Slippers B, Wingfield MJ, Wingfield BD (2012a) High levels of genetic diversity and cryptic recombination is widespread in introduced Diplodia pinea populations. Australas Plant Pathol 41:41-46

Bihon W, Slippers B, Burgess T, Wingfield MJ, Wingfield BD (2012b) Diverse sources of infection and cryptic recombination revealed in south African Diplodia pinea populations. Fungal Biology 116: 112-120

Billones-Baaijens R, Jones E, Ridgway H, Jaspers M (2012) Pathogenicity of a New Zealand grapevine isolate of Neofusicoccum macroclavatum on Eucalyptus globulus. New Zealand Plant Protection 65:262-266

Burgess T, Wingfield MJ (2002) Quarantine is important in restricting the spread of exotic seed-borne tree pathogens in the southern hemisphere. Int For Rev 4:56-65 
Burgess TI, Wingfield MJ (2017) Pathogens on the move: a 100-year global experiment with planted eucalypts. Bioscience 67:14-25

Burgess TI, Gordon TR, Wingfield MJ, Wingfield BD (2004a) Geographic isolation of Diplodia scrobiculata and its association with native Pinus radiata. Mycol Res 108:1399-1406

Burgess TI, Wingfield MJ, Wingfield BD (2004b) Global distribution of Diplodia pinea genotypes revealed using simple sequence repeat (SSR) markers. Australas Plant Pathol 33:513-519

Burgess TI, Sakalidis ML, Hardy GESJ (2006) Gene flow of the canker pathogen Botryosphaeria australis between Eucalyptus globulus plantations and native eucalypt forests inWestern Australia. Austral Ecol 31:559-566

Burgess TI, Crous CJ, Slippers B, Hantula J, Wingfield MJ (2016) Tree invasions and biosecurity: eco-evolutionary dynamics of hitchhiking fungi. AoB Plants 8:plw076

Chen SF, Pavlic D, Roux J, Slippers B, Xie Y, Wingfield MJ, Zhou X (2011) Characterization of Botryosphaeriaceae from plantation grown Eucalyptus species in South China. Plant Pathol 60:739-751

Conradie DC (2012) South Africa's climatic zones: today, tomorrow. International Green Building Conference and Exhibition; Future Trends and Issues Impacting on the Built Environment, Sandton, South Africa

Copes WE, Hendrix FF (2004) Effect of temperature on sporulation of Botryosphaeria dothidea, B. obtusa, and B. rhodina. Plant Dis 88: 292-296

Crous PW, Phillips AJL, Baxter AP (2000) Phytopathogenic fungi from South Africa. Department of Plant Pathology Press, Stellenbosch, South Africa

Crous PW, Slippers B, Wingfield MJ, Rheeder J, Marasas WFO, Philips AJL, Alves A, Burgess T, Barber P, Groenewald JZ (2006) Phylogenetic lineages in the Botryosphaeriaceae. Stud. Mycol 55: 235-253

Crous CJ, Jacobs SM, Esler KJ (2012) Drought-tolerance of an invasive alien tree, Acacia mearnsii and two native competitors in fynbos riparian ecotones. Biol Invasions 14:619-631

Crous PW, Groenewald JZ, Slippers B, Wingfield MJ (2016) Global food and fibre security threatened by current inefficiencies in fungal identification. Philos Trans R Soc B 371:20160024

Cruywagen EM, Slippers B, Roux J, Wingfield MJ (2017) Phylogenetic species recognition and hybridisation in Lasiodiplodia: a case study on species from baobabs. Fungal Biol 121:420436 
Cunnington JH, Priest MJ, Powney RA, Cother NJ (2007) Diversity of Botryosphaeria species on horticultural plants in Victoria and new South Wales. Australas Plant Pathol 36:157-159

Damm U, Crous PW, Fourie PH (2007) Botryosphaeriaceae as potential pathogens of Prunus species in South Africa, with descriptions of Diplodia africana and Lasiodiplodia plurivora sp. nov. Mycologia 99:664-680

Denman S, Crous PW, Groenewald JZ, Slippers B, Wingfield BD, Wingfield MJ (2003) Circumscription of Botryosphaeria species associated with Proteaceae based on morphology and DNA sequence data. Mycologia 95:294-307

Epstein L, Sukhwinder K, Vandergheynst J (2008) Botryosphaeria-related dieback and control investigated in noncoastal California grapevines. Calif Agric 62:161-166

Flowers J, Hartman J, Vaillancourt L (2003) Detection of latent Sphaeropsis sapinea infections in Austrian pine tissues using nested-polymerase chain reaction. Phytopathology 93:1471-1477

Fourie $P$, Halleen F (2001) Diagnosis of fungal diseases and their involvement in dieback diseases of young vines. Winelands 12:19-23

Geldenhuys CJ (1997) Native forest regeneration in pine and eucalypt plantations in Northern Province, South Africa. For Ecol Manag 99:101-116

Gibson IAS (1975) The Leguminosae. In diseases of forest trees widely planted as exotics in the tropics and southern hemisphere. Part I. Important members of the Myrtaceae, Leguminosae, Verbenaceae and Meliaceae

Heath RN, Roux J, Slippers B, Drenth A, Pennycook S, Wingfield BD, Wingfield MJ (2011) Occurrence and pathogenicity of Neofusicoccum parvum and N. mangiferae on ornamental Tibouchina species. For Pathol 41:48-51

Http://En.Wikipedia.Org/Wiki/Climate_of_South_Africa (2007)

Http://Www.Forestry.Co.Za/Statistical-Data/ (2011) South African Forestry and Forest Products Industry Facts [Online]

Iturritxa E, Slippers B, Mesanza N, Wingfield MJ (2011) First report of Neofusicoccum parvum causing canker and die-back of Eucalyptus in Spain. Australasian Plant Dis Notes 6:57-59

Jami F, Slippers B, Wingfield MJ, Gryzenhout M (2012) Five new species of the Botryosphaeriaceae from Acacia karroo in South Africa. Cryptogam Mycol 33:245-266

Jami F, Slippers B, Wingfield MJ, Gryzenhout M (2013) Greater Botryosphaeriaceae diversity in healthy than associated diseased Acacia karroo tree tissues. Australas Plant Pathol 42:421-430 
Jami F, Slippers B, Wingfield MJ, Gryzenhout M (2014) Botryosphaeriaceae species overlap on four unrelated, native south African hosts. Fungal Biol 118:168-179

Jami F, Slippers B, Wingfield MJ, Gryzenhout M (2015) Temporal and spatial variation of Botryosphaeriaceae associated with Acacia karroo in South Africa. Fungal Ecol 15:51-62

KemlerM, Garnas J, Wingfield MJ, GryzenhoutM, Pillay K-A, Slippers B (2013) lon torrent PGM as tool for fungal community analysis: a case study of endophytes in Eucalyptus grandis reveals high taxonomic diversity. PLoS One 8:e81718

Linde C, Kemp G,WingfieldM(1997) First report of Sphaeropsis canker on cypress in South Africa. Eur J For Pathol 27:173-177

Maleme H (2009) Characterisation of latent Botryosphaeriaceae on diverse Eucalyptus species. Department of Microbiology and Plant Pathology, University of Pretoria, South Africa, M.Sc. Thesis

Marincowitz S,Groenewald JZ,WingfieldMJ, Crous PW(2008) Species of Botryosphaeriaceae occurring on Proteaceae. Persoonia 21:111-118

Marsberg A, Kemler M, Jami F, Nagel JH, Postma-Smidt A, Naido S, Wingfield MJ, Crous PW, Spatafora J, Hesse CN (2017) Botryosphaeria dothidea: a latent pathogen of global importance to woody plant health. Mol Plant Pathol 18:477-488

Martínez-Minaya J, Conesa D, López-Quílez A, Vicent A (2015) Climatic distribution of citrus black spot caused by Phyllosticta citricarpa. A historical analysis of disease spread in South Africa. Eur J Plant Pathol 143:69-83

Mehl JWM, Slippers B, Roux J, Wingfield MJ (2011) Botryosphaeriaceae associated with Pterocarpus angolensis (kiaat) in South Africa. Mycologia 103:534-553

Mehl J, Slippers B, Roux J, Wingfield M (2014) Botryosphaeriaceae associated with die-back of Schizolobium parahyba trees in South Africa and Ecuador. For Pathol 44:396-408

Mehl JW, Slippers B, Roux J, Wingfield MJ (2017a) Overlap of latent pathogens in the Botryosphaeriaceae on a native and agricultural host. Fungal Biol 121:405-149

Mehl J,Wingfield MJ, Roux J, Slippers B (2017b) Invasive everywhere? Phylogeographic analysis of the globally distributed tree pathogen Lasiodiplodia theobromae. Forests 8:145

Michailides TJ, Morgan DP (1992) Effects of temperature and wetness duration on infection of pistachio by Botryosphaeria dothidea and management of disease by reducing duration of irrigation. Phytopathology 82:1399-1406

Mohali S, Slippers B, Wingfield MJ (2007) Identification of Botryosphaeriaceae from Eucalyptus, Acacia and Pinus in Venezuela. Fungal Divers 25:103-125 
Nakabonge G (2002) Diseases associated with plantation forestry in Uganda. University of Pretoria, South Africa, MSc Thesis. Department of Microbiolgy and Plant Pathology

Ndove L (2015) Botryosphaeriaceae associated with Southern Hemisphere gymnosperms. University of Pretoria, South Africa, MSc Thesis. Department of Microbiolgy and Plant Pathology

Osorio JA, Crous CJ, De Beer ZW, Wingfield MJ, Roux J (2017) Endophytic Botryosphaeriaceae, including five new species, associated with mangrove trees in South Africa. Fungal Biol 121:361-393

Pavlic D, Slippers B, Coutinho TA, Gryzenhout M,Wingfield MJ (2004) Lasiodiplodia gonubiensis sp. nov., a new Botryosphaeria anamorph from native Syzygium cordatum in South Africa. Stud Mycol 50:313-322

Pavlic D, Slippers B, Coutinho TA, Wingfield MJ (2007) Botryosphaeriaceae occurring on native Syzygium cordatum in South Africa and their potential threat to Eucalyptus. Plant Pathol 56:624-636

Pavlic D, Slippers B, Coutinho TA, Wingfield MJ (2009) Multiple gene genealogies and phenotypic data reveal cryptic species of the Botryosphaeriaceae: a case study on the Neofusicoccum parvum/ N. ribis Complex. Mol Phylogenet Evol 51:259-268

Pérez C, Altier N, Simeto S, Wingfield M, Slippers B, Blanchette R (2008) Botryosphaeriaceae from Eucalyptus and native Myrtaceae in Uruguay. Agrociencia 12:19-30

Pérez CA, Wingfield MJ, Slippers B, Altier NA, Blanchette RA (2009) Neofusicoccum eucalyptorum, a Eucalyptus pathogen, on native Myrtaceae in Uruguay. Plant Pathol 58:964-970

Phillips A, Alves A, Abdollahzadeh J, Slippers B, Wingfield M, Groenewald J, Crous P (2013) The Botryosphaeriaceae: genera and species known from culture. Stud Mycol 76:51-167

Pillay K, Slippers B, Wingfield MJ, Gryzenhout M (2013) Diversity and distribution of coinfecting Botryosphaeriaceae from Eucalyptus grandis and Syzygium cordatum in South Africa. SAfr J Bot 84:38-43

Punithalingam E (1976) Botryodiplodia theobromae. Commonwealth Mycological Institute, Kew, Surrey, England

Punithalingam E (ed) (1980) Plant diseases attributed to Botryodiplodia theobromae. BibliotecaMycologica, J. Cramer, Berlin, Germany, In Rodas C, Slippers B, Gryzenhout M, Wingfield M (2009) Botryosphaeriaceae associated with eucalyptus canker diseases in Colombia. For Pathol 39:110-123 
Rodríguez-Gálvez E, Guerrero P, Barradas C, Crous PW, Alves A (2017) Phylogeny and pathogenicity of Lasiodiplodia species associated with dieback of mango in Peru. Fungal Biol 121:425-465

Roux J (1998) Diseases of Acacia mearnsii in South Africa with particular reference to Ceratocystis wilt. PhD thesis, University of Pretoria, Pretoria, South Africa

Roux J, Wingfield MJ (1997) Survey and virulence of fungi occurring on diseased Acacia mearnsii in South Africa. Forest Ecol Manag 99: 327-336

Roux J, Wingfield MJ, Morris MJ (1997) Botryosphaeria dothidea as a pathogen of Acacia mearnsii in South Africa. S Afr J Sci 99:327-336

Roux J, Coutinho T, Wingfield M, Bouillet J (2000) Diseases of plantation Eucalyptus in the Republic of Congo. S Afr J Sci 96:454-456

Sakalidis ML, Hardy GESJ, Burgess TI (2011) Class III endophytes, clandestine movement amongst hosts and habitats and their potential for disease; a focus on Neofusicoccum australe. Australas Plant Pathol 40:510-521

Sakalidis ML, Slippers B, Wingfield BD, Hardy GESJ, Burgess TI (2013) The challenge of understanding the origin, pathways and extent of fungal invasions: global populations of the Neofusicoccum parvum-N. ribis species complex. Divers Distrib 19:873-1094

Slippers B (2003) Taxonomy, phylogeny- and ecology of botryosphaeriaceous fungi occurring on various woody hosts. Ph.D. Thesis, Department of Microbiology and Plant Pathology, University of Pretoria, South Africa

Slippers B,Wingfield MJ (2007) Botryosphaeriaceae as endophytes and latent pathogens of woody plants: diversity, ecology and impact. Fungal Biol Rev 21:90-106

Slippers B, Fourie G, Crous PW, Coutinho TA, Wingfield BD, Carnegie AJ, Wingfield MJ (2004) Speciation and distribution of Botryosphaeria spp. on native and introduced Eucalyptus trees in Australia and South Africa. Stud Mycol 50:343-358

Slippers B, Stenlid J, Wingfield MJ (2005) Emerging pathogens: fungal host jumps following anthropogenic introduction. Trends Ecol Evol 20:420-421

Slippers B, Smit WA, Crous PW, Coutinho TA, Wingfield BD, Wingfield MJ (2007) Taxonomy, phylogeny and identification of Botryosphaeriaceae associated with pome and stone fruit trees in South Africa and other regions of the world. Plant Pathol 56:128-139

Slippers B, Burgess T, Pavlic D, Ahumada R, Maleme H, Mohali S, Rodas C, Wingfield MJ (2009) A diverse assemblage of Botryosphaeriaceae infect Eucalyptus in native and nonnative environments. South Forests 71:101-110 
Slippers B, Boissin E, Phillips A, Groenewald J, Lombard L, Wingfield M, Postma A, Burgess T, Crous $P$ (2013) Phylogenetic lineages in the Botryosphaeriales: a systematic and evolutionary framework. Stud Mycol 76:31-49

Slippers B, Roux J, Wingfield MJ, Van Der Walt FJJ, Jami F, Marais GJ (2014) Confronting the constraints of morphological taxonomy in the fungi: a Botryosphaeriaceae case study.

Persoonia 33:155-168

Slippers B, Crous P, Jami F, Groenewald J, WingfieldM(2017) Diversity in the Botryosphaeriales: looking back, looking forward. Fungal Biol 121:307-321

Smith H, Kemp GHJ, Wingfield MJ (1994) Canker and die-back of Eucalyptus in South Africa caused by Botryosphaeria dothidea. Plant Pathol 43:1031-1034

Smith H, Wingfield MJ, Petrini O (1996a) Botryosphaeria dothidea endophytic in Eucalyptus grandis and Eucalyptus nitens in South Africa. For Ecol Manag 89:189-195

Smith H, Wingfield MJ, Crous PW, Coutinho TA (1996b) Sphaeropsis sapinea and Botryosphaeria dothidea endophytic in Pinus spp. and Eucalyptus spp. in South Africa. S Afr J Bot 62:86-88

Smith H, Wingfield M, De Wet J, Coutinho T (2000) Genotypic diversity of Sphaeropsis sapinea from South Africa and northern Sumatra. Plant Dis 84:139-142

Smith H, Crous PW, Wingfield MJ, Coutinho TA, Wingfield BD (2001) Botryosphaeria eucalyptorum sp. nov., a new species in the B. dothidea complex on Eucalyptus in South Africa. Mycologia 93:277-285

Stanosz GR, Carlson JC (1996) Association of mortality of recently planted seedlings and established saplings in red pine plantations with Sphaeropsis collar rot. Plant Dis 80:750753

Steenkamp ET, Wingfield MJ (2013) Global forest research, science education and community service positively impacted by a unique Centre of Excellence in tree health biotechnology. South Forests 75:71-80

Swart H (1986) Australian leaf-inhabiting fungi XXII. Microthyrium-like fungi on Eucalyptus. T Brit Mycol Soc 87:81-91

Swart WJ, Wingfield MJ (1991) Biology and control of Sphaeropsis sapinea on Pinus species in South Africa. Plant Dis 75:761-766

Swart WJ, Knox Davies PS, Wingfield MJ (1985) Sphaeropsis sapinea, with special reference to its occurrence on Pinus spp. in South Africa. South African Forestry Journal 35:1-8

Swart W, Wingfield M, Knox-Davies P (1987) Conidial dispersal of Sphaeropsis sapinea in three climatic regions of South Africa. Plant Dis 71:1038-1040 
Taylor K, Barber PA, Hardy GESJ, Burgess TI (2009) Botryosphaeriaceae from tuart (Eucalyptus gomphocephala) woodland, including descriptions of four new species. Mycol Res 113: 337-353

Úrbez-Torres J, Battany M, Bettiga L, Gispert C, Mcgourty G, Roncoroni J, Smith R, Verdegaal $\mathrm{P}$, Gubler W (2010) Botryosphaeriaceae species spore-trapping studies in California vineyards. Plant Dis 94: 717-724

Urbez-Torres J, Bruez E, Hurtado J, Gubler W (2010) Effect of temperature on conidial germination of Botryosphaeriaceae species infecting grapevines. Plant Dis 94:1476-1484

Van Der Linde JA, Begoude BAD, Roux J (2010) High levels of Botryosphaeriaceae diversity on native and introduced Acacia spp. in South Africa. Proceedings of the 9th Conference of the International Mycological Society, 2010 Edinburgh, Scotland

Van Der Linde J, Six DL, Wingfield MJ, Roux J (2011) Lasiodiplodia species associated with dying Euphorbia ingens in South Africa. South Forests 73:165-173

Van Niekerk JM, Crous PW, Groenewald JZ, Fourie PH, Halleen F (2004) DNA phylogeny, morphology and pathogenicity of Botryosphaeria species on grapevines. Mycologia 96:781798

Van Niekerk J, Fourie P, Hallenn F, Crous P (2006) Botryosphaeria spp. as grapevine trunk disease pathogens. Phytopathol Mediterr 45:43-54

Van Niekerk J, BesterW, Halleen F, Crous P, Fourie P (2010a) First report of Lasiodiplodia crassispora as a pathogen of grapevine trunks in South Africa. Plant Dis 94:1063-1063

Van Niekerk JM, Calitz FJ, Halleen F, Fourie PH (2010b) Temporal spore dispersal patterns of grapevine trunk pathogens in South Africa. Eur J Plant Pathol 127:375-390

Van Niekerk J, Strever AE, Du Toit GP, Halleen F, Fourie PH (2011) Influence of water stress on Botryosphaeriaceae disease expression in grapevines. Phytopathol Mediterr 50:151-165

Zenni RD, Dickie IA, Wingfield MJ, Hirsch H, Crous CJ, Meyerson LA, Burgess TI, Zimmermann TG, Klock MM, Siemann E (2016) Evolutionary dynamics of tree invasions: complementing the unified framework for biological invasions. AoB Plants 9:plw085

Zwolinski J, Swart W, Wingfield M (1990) Economic impact of a posthail outbreak of dieback induced by Sphaeropsis sapinea. Eur J For Pathol 20:405-411

Zwolinski J, Swart W, Wingfield M (1995) Association of Sphaeropsis sapinea with insect infestation following hail damage of Pinus radiata. For Ecol Manag 72:293-298 


\section{Supplementary material}

Table2. Botryosphaeriales presence/absence in Namibia and South Africa.

\begin{tabular}{|c|c|c|c|c|c|c|c|c|c|c|c|c|c|c|c|c|c|c|c|c|c|c|c|c|c|c|c|c|c|}
\hline & \multirow[b]{2}{*}{ Namibia } & \multicolumn{28}{|c|}{ *Sites in South Africa } \\
\hline & & 1 & 2 & 3 & 4 & 5 & 6 & 7 & 8 & 9 & 10 & 11 & 12 & 13 & 14 & 15 & 16 & 17 & 18 & 19 & 20 & 21 & 22 & 23 & 24 & 25 & 26 & 27 & 28 \\
\hline Aplosporella africana & + & - & - & - & - & - & - & - & - & - & - & - & - & - & - & - & - & - & - & - & - & - & - & - & - & - & - & - & - \\
\hline A. javeedii & - & - & - & - & - & + & - & - & - & - & - & - & - & - & - & - & - & - & - & - & - & - & - & - & - & - & - & - & - \\
\hline A. prunicola & - & - & - & - & - & + & - & - & - & - & - & - & - & - & - & - & - & - & - & - & - & - & - & - & - & - & - & - & - \\
\hline A. papillata & - & - & - & - & - & + & - & - & - & - & - & - & - & - & - & - & - & - & - & - & - & - & - & - & - & - & - & + & - \\
\hline Botryosphaeria & & & & & & & & & & & & & & & & & & & & & & & & & & & & & \\
\hline dothidea & + & + & + & - & + & + & + & + & + & - & - & + & - & - & + & + & - & + & + & + & - & - & - & - & - & - & + & - & - \\
\hline B. atrovirens & - & - & - & - & + & + & - & - & - & - & - & - & - & - & - & - & - & - & - & - & - & - & - & + & - & - & - & - & - \\
\hline B. avasmontanum & - & + & + & - & + & + & - & - & - & - & - & + & + & - & - & - & - & - & - & - & - & - & - & + & + & - & - & - & - \\
\hline B. fabiceriana & - & + & - & - & - & + & - & - & - & - & - & - & - & - & - & - & - & - & - & - & - & - & - & - & - & - & - & - & - \\
\hline Diplodia allocellula & - & - & - & - & - & - & - & - & - & - & - & - & - & - & - & - & - & - & - & - & - & - & + & - & - & - & - & - & - \\
\hline D. estuarina & - & - & - & - & + & - & - & - & - & - & - & + & + & + & - & + & + & - & - & - & - & - & - & - & + & - & - & - & - \\
\hline D. mutila & - & - & - & - & - & - & - & - & - & - & - & + & - & - & - & - & - & - & - & - & - & - & - & - & - & - & - & - & - \\
\hline D. pseudpseriata & - & - & - & - & - & - & - & - & - & - & - & + & - & - & - & - & - & - & - & - & - & - & + & + & + & + & - & - & - \\
\hline D. seriata & - & - & - & + & - & - & - & - & - & - & - & - & - & - & - & - & - & - & - & - & - & - & - & - & - & - & - & - & - \\
\hline D. sapinea & - & - & - & - & - & - & - & - & - & - & - & - & - & + & - & - & - & - & - & - & - & - & - & - & - & - & - & - & - \\
\hline D. scrobiculata & - & - & - & - & - & - & - & - & - & - & - & - & - & - & - & - & - & - & - & - & - & - & - & - & - & - & - & - & - \\
\hline
\end{tabular}


*Sites in South Africa

$\begin{array}{lllllllllllllllllllllllllllll}\text { Namibia } & 1 & 2 & 3 & 4 & 5 & 6 & 7 & 8 & 9 & 10 & 11 & 12 & 13 & 14 & 15 & 16 & 17 & 18 & 19 & 20 & 21 & 22 & 23 & 24 & 25 & 26 & 27 & 28\end{array}$

\begin{tabular}{|c|c|c|c|c|c|c|c|c|c|c|c|c|c|c|c|c|c|c|c|c|c|c|c|c|c|c|c|c|c|}
\hline Dothiorella brevicollis & - & - & - & - & - & - & - & - & - & - & - & - & - & - & - & - & - & - & - & - & - & - & - & - & + & - & - & - & - \\
\hline Do. oblonga & - & - & - & - & - & - & - & - & - & - & - & - & - & - & - & - & - & - & - & - & - & - & + & - & + & + & - & - & - \\
\hline Do. capriamissii & - & + & - & - & - & + & - & - & - & - & - & - & - & - & - & - & - & - & - & - & - & - & - & - & - & - & - & - & - \\
\hline Do. dulcispinea & + & - & - & - & - & + & - & - & - & - & - & - & - & - & - & - & - & - & - & - & - & - & - & - & - & - & - & - & - \\
\hline Do. pretoriensis & - & - & - & - & - & + & - & - & - & - & - & - & - & - & - & - & - & - & - & - & - & - & - & - & - & - & - & - & - \\
\hline Do. rosulata & + & - & + & - & - & - & - & - & - & - & - & - & - & - & - & - & - & - & - & - & - & - & - & - & - & - & - & - & - \\
\hline Do. viticola & + & - & - & - & - & - & - & - & - & - & - & - & - & - & - & - & - & - & - & - & - & - & - & - & - & - & - & - & - \\
\hline Eutiarosporella africana & - & - & - & - & - & - & - & - & - & - & - & - & - & - & - & - & - & - & - & - & - & - & - & - & - & - & - & - & - \\
\hline E graminis & - & + & + & - & - & - & - & - & - & - & - & - & + & - & - & - & - & - & - & - & - & - & - & - & - & - & - & - & - \\
\hline E. tritici & - & + & + & - & + & + & - & - & - & - & - & - & + & - & - & - & - & - & - & - & - & - & - & + & + & - & - & - & + \\
\hline E. urbis-rosarum & - & - & - & - & - & + & - & - & - & - & - & - & - & - & - & - & - & - & - & - & - & - & - & - & - & - & - & - & - \\
\hline Lasiodiplodida & & & & & & & & & & & & & & & & & & & & & & & & & & & & & \\
\hline avicenniae & + & - & - & - & - & + & - & - & - & - & - & + & - & - & - & - & - & - & - & - & - & - & - & - & - & - & - & - & - \\
\hline L. bruguierae & - & + & - & - & - & + & - & - & - & - & - & - & - & + & - & - & - & - & + & - & - & - & + & - & + & - & + & - & - \\
\hline L. crassispora & - & - & - & - & - & - & - & - & - & - & - & + & - & - & - & - & - & - & - & - & - & + & - & - & - & - & - & - & - \\
\hline L euphorbiicola & - & - & + & - & - & - & - & - & - & - & - & - & + & - & - & - & - & - & - & - & - & - & - & - & - & - & - & - & - \\
\hline L. gilanensis & - & - & - & - & + & - & - & - & - & - & - & - & - & - & - & - & - & - & - & - & - & - & - & - & - & - & - & - & - \\
\hline L. gonubiensis & - & + & + & - & - & + & - & - & - & - & - & + & + & - & - & - & - & - & - & - & - & - & - & - & - & - & - & - & - \\
\hline L. iraniensis & - & + & - & - & - & - & - & - & - & - & - & + & - & + & - & - & - & - & - & - & - & - & - & - & + & - & - & - & - \\
\hline
\end{tabular}


${ }^{*}$ Sites in South Africa

$\begin{array}{llllllllllllllllllllllllllllll}\text { Namibia } & 1 & 2 & 3 & 4 & 5 & 6 & 7 & 8 & 9 & 10 & 11 & 12 & 13 & 14 & 15 & 16 & 17 & 18 & 19 & 20 & 21 & 22 & 23 & 24 & 25 & 26 & 27 & 28\end{array}$

\begin{tabular}{|c|c|c|c|c|c|c|c|c|c|c|c|c|c|c|c|c|c|c|c|c|c|c|c|c|c|c|c|c|c|}
\hline L. mahajangana & + & + & - & - & - & - & - & - & - & - & - & - & + & - & - & - & - & - & - & - & - & - & - & - & - & - & - & - & - \\
\hline L. pseudotheobromae & + & + & - & - & - & - & - & - & - & - & - & - & + & + & - & - & - & - & - & - & - & - & - & - & - & - & - & - & - \\
\hline L. plurivora & - & - & - & - & - & - & - & - & - & + & - & - & - & - & - & - & - & - & - & - & + & - & - & - & + & - & - & - & - \\
\hline L. pyriformis & + & - & - & - & - & + & - & - & - & - & + & + & - & - & - & - & - & - & - & - & - & - & - & - & + & - & - & - & + \\
\hline L. theobromae & - & + & - & - & - & - & - & - & - & - & - & + & - & - & - & - & - & - & - & - & - & - & - & - & + & - & - & - & - \\
\hline Neofusicoccum sp.1 & - & - & - & - & - & + & - & - & - & - & - & - & - & - & - & - & - & - & - & - & - & - & - & - & - & - & - & - & - \\
\hline Neofusicoccum sp.2 & + & - & - & - & - & + & - & - & - & - & - & - & - & - & - & - & - & - & - & - & - & - & - & + & - & - & - & - & - \\
\hline N. australe & - & - & + & - & - & - & - & - & - & - & - & - & - & - & - & - & - & - & - & - & - & - & - & - & - & - & - & - & - \\
\hline N. cordaticola & - & - & + & - & - & - & - & - & - & - & - & - & - & - & - & - & - & - & - & - & - & - & - & - & - & - & - & - & - \\
\hline N. crypto-australe & + & - & - & - & - & - & - & - & - & - & - & + & - & - & - & - & - & - & - & - & - & - & - & - & - & - & - & - & - \\
\hline N. eucalyptorum & - & - & - & - & - & - & - & - & - & - & - & - & - & - & - & - & - & - & - & - & - & - & - & - & - & - & - & - & - \\
\hline N. eucalypti & - & - & - & - & - & + & - & - & + & + & + & + & - & - & - & - & - & - & - & - & - & - & - & + & - & + & - & - & + \\
\hline N. kwambonambiense & - & - & - & - & - & - & - & - & - & - & - & + & - & - & - & - & - & - & - & - & - & - & - & - & - & - & - & - & - \\
\hline N. luteum & - & + & - & - & - & + & - & - & - & - & - & - & - & - & - & - & - & - & - & - & - & - & - & - & - & - & - & - & - \\
\hline N. mangiferum & - & - & - & - & - & + & - & - & - & - & - & - & - & - & - & - & - & - & - & - & - & - & - & - & - & - & - & - & - \\
\hline N. mediterraneum & - & + & - & - & + & + & - & - & + & - & - & + & - & - & - & - & - & - & - & - & - & - & - & - & - & - & - & - & - \\
\hline N. mangroviorum & - & - & - & - & - & - & - & - & - & - & - & + & - & - & - & - & - & - & - & - & - & - & - & - & - & - & - & - & - \\
\hline N. parvum & - & + & - & - & - & + & - & - & - & + & - & + & - & - & - & - & - & - & - & - & - & - & - & + & - & - & - & - & + \\
\hline
\end{tabular}




\begin{tabular}{|c|c|c|c|c|c|c|c|c|c|c|c|c|c|c|c|c|c|c|c|c|c|c|c|c|c|c|c|c|c|}
\hline & \multirow[b]{2}{*}{ Namibia } & \multicolumn{28}{|c|}{${ }^{*}$ Sites in South Africa } \\
\hline & & 1 & 2 & 3 & 4 & 5 & 6 & 7 & 8 & 9 & 10 & 11 & 12 & 13 & 14 & 15 & 16 & 17 & 18 & 19 & 20 & 21 & 22 & 23 & 24 & 25 & 26 & 27 & 28 \\
\hline N. ptrotearum & - & - & - & - & - & - & - & - & - & - & - & - & - & - & - & - & - & - & - & - & - & - & - & - & - & - & - & - & - \\
\hline N. umdonicola & - & + & - & - & - & - & - & - & - & - & - & + & - & - & - & - & - & - & - & - & - & - & - & - & - & - & - & - & - \\
\hline N. ursorum & - & - & - & - & - & - & - & - & - & - & - & - & - & - & - & - & - & - & - & - & - & - & - & - & - & - & - & - & - \\
\hline N. vitifusiforme & - & - & - & - & - & - & - & - & - & - & - & + & - & - & - & - & - & - & - & - & - & - & - & - & - & - & - & - & - \\
\hline N. viticlavatum & - & - & - & - & - & - & - & - & - & - & - & - & - & - & - & - & - & - & - & - & - & - & - & - & - & - & - & - & - \\
\hline $\begin{array}{l}\text { Oblongocollomyces } \\
\text { variabili }\end{array}$ & + & - & - & - & - & - & - & - & - & - & - & - & - & - & - & - & - & - & - & - & - & - & - & - & - & - & - & - & - \\
\hline $\begin{array}{l}\text { Pseudofusicoccum } \\
\text { violaceum }\end{array}$ & - & - & - & - & - & - & - & - & - & - & - & - & - & - & - & - & - & - & - & - & - & - & - & - & - & - & - & - & - \\
\hline Ps. olivaceum & - & + & - & - & + & - & - & - & - & - & - & - & - & - & - & - & - & - & - & - & - & - & - & - & - & - & - & - & - \\
\hline Saccharata proteae & - & - & - & - & - & - & - & - & - & - & - & - & - & - & - & - & - & - & - & - & - & - & - & - & + & - & - & - & - \\
\hline Spaeropsis Porosa & - & - & - & - & - & - & - & - & - & - & - & - & - & - & - & - & - & - & - & - & - & - & - & - & + & - & - & - & - \\
\hline
\end{tabular}

* South African sites in the map: 1= Limpopo, Mokopane, Tzaneen (Limpopo Province); 2 = Sabie, Pretoriuskop (Mpumalanga Province), Phalaborwa (Limpopo Province); $3=$ Bracken Hill (Swaziland); 4= Mpumalanga, Piet Retief (Mpumalanga Province); $5=$ Pretoria (Gauteng Province), Tweefontein (Mpumalanga Province), Modimolle (Limpopo Province); $\mathbf{6 =}$ Delareyville (North West Province); $\mathbf{7}=$ Bloemhof (North West Province); $8=$ Bloemfontein (Free State Provincce); $9=$ Aliwal North (Eastern Cape Province); 10= Wasbank (KwaZulu-Natal Province); 11= KwaZulu-Natal Province; 12= Richards Bay, Mkuze, Kwambonambi, Kosi Bay, Sodwana Bay (KwaZulu-Natal Province); 13= Haga Haga, East London (Eastern Cape Province); 14= Queenstown (Eastern Cape Province); 15= Eastern Cape Province; 16= Humansdorp (Eastern Cape Province); 17= Jansenville (Eastern Cape Province); 18= Graaff-Reinet (Eastern Cape Province); 19= Beaufort West (Western Cape Province); 20= Calitzdorp, Buffelskloof (Western Cape Province); 21= George (Western Cape Province); 22= Hermanus, Elgine, Jonkershoek (Western Cape Province); 23= Cape Town (Western Cape Province); 24= Western Cape Province; 25= Ceres, Swellendam, Robertson (Western Cape Province); 26= Hondeklip Bay (Northern Cape Province); 27= Prieska (Northern Cape Province); 28= Kuruman, Augrabies, Upington (Northern Cape Province). 